\title{
مقروئية الصحف الورقية في ظل منافسة الصحافة الإلكترونية \\ (دراسة ميدانية للصحف اليومية اليمنية)
}

د/عبد الملك الدناني

أستاذ الاتصال المشارك - كلية الإمارات للتكنولوجيا ـ أبو ظبي

كلية الإعلام م جامعة صنعاء

المستخلص

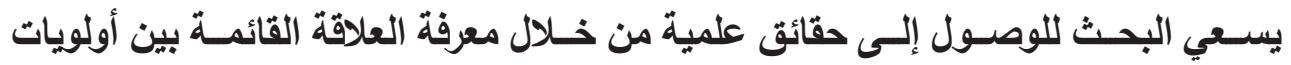

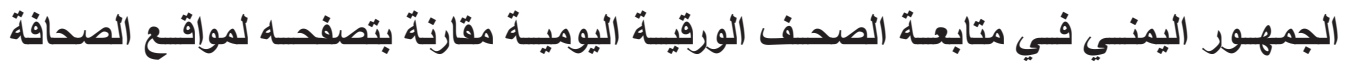

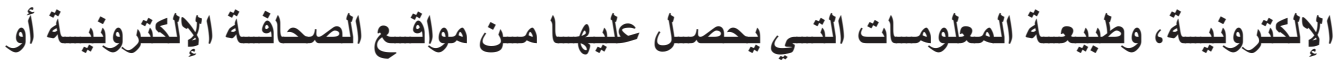

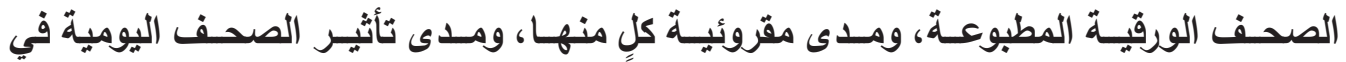

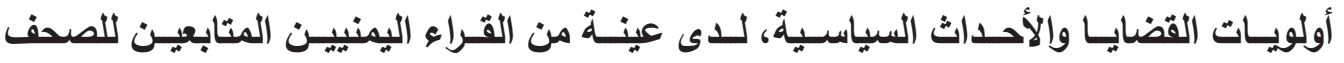

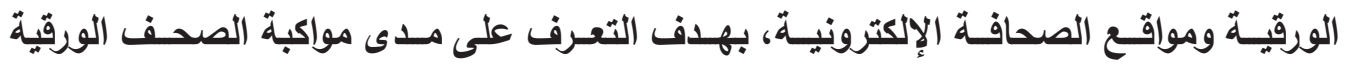

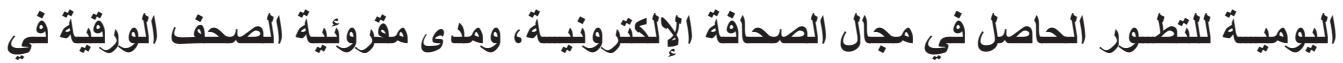

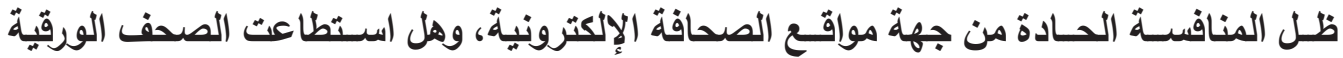

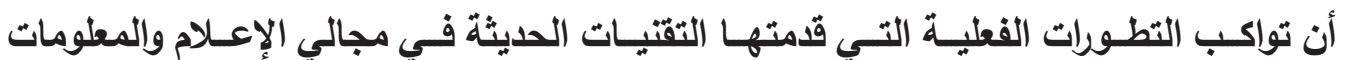

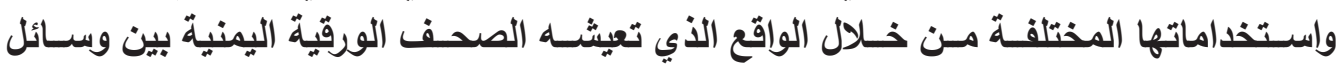

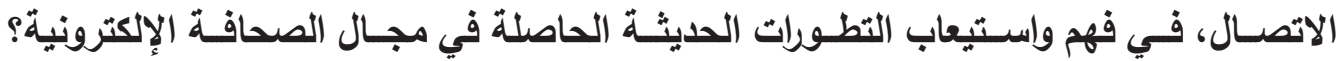

Paper Newspapers Reading under the Competition of Online Journalism (A Field Study of Yemeni Daily Newspapers)

Ph.D. Abdul Malik Aldanana

Emirates College of Technology - Abu Dhabi

College of Mass Communication

Sanaa University

The researcher seeks to get scientific facts through knowing the relationship between the priorities of Yemeni audience in follow-up paper

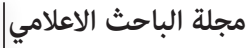


daily newspapers compared to surfing publics the online journalism sites and the nature of information obtained from online journalism sites and printed paper newspapers and the impact of the daily newspapers in the priority of issues and political events among a sample of a group of Yemeni readers in order to identify the extent to keep up the paper daily newspapers of the development in the field of online journalism and the extent of reading paper newspapers under the intense competition by online journalism sites, and are paper newspapers able to keep pace with the actual developments provided by modern technologies in the field of media and information and their various uses through the reality of Yemeni paper newspapers among means of communication to understand and comprehend the recent developments in the field of electronic newspapers.

\section{الإطار المنهجي للبحث أولاً: أهمية البحث}

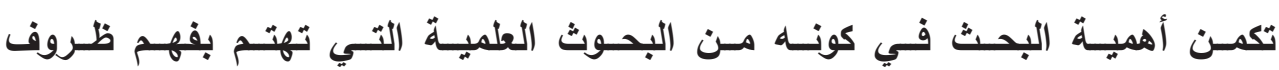

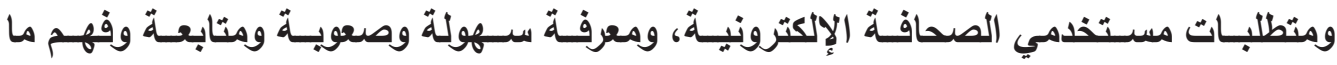

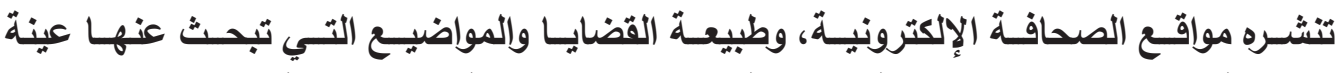

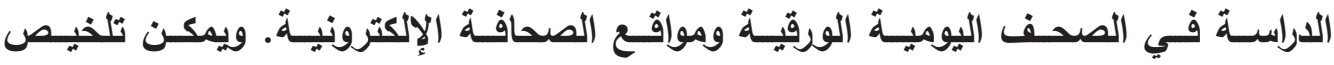

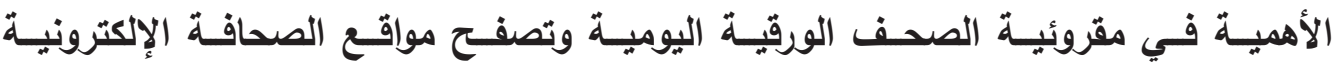

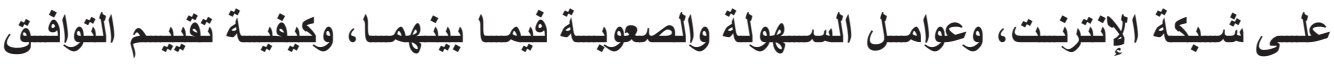

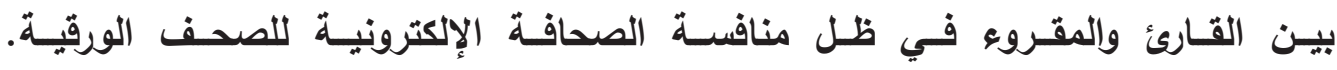
ثانياً: مشكلة البحث وتساؤلاته

تشـير بعض الكتابات إلى أن دول العالم سـوف تثهر خلال الأعوام القليلة القادمة انقراض

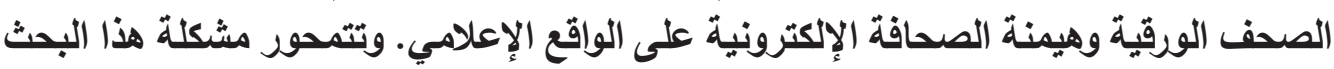

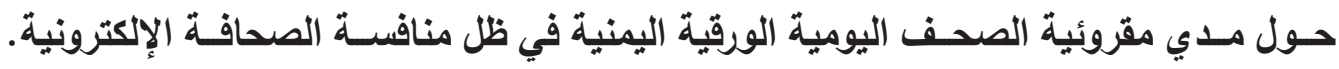
ويمكن صياغة المشكلة من خلال التساؤلين الرئيسيين الآتيين: • ما مدى اهتمام ومتابعة القراء للصحف الورقية اليومية في اليمن؟ 
• ما طبيعة الضغوط التي تمارسها مواقع الصحافة الإكترونية على الصحف الورقية؟

ويتفرع من هذين التساؤلين الرئيسين العديد من الأسئلة، منها: 1. ما مدى اهتمام الجمهور اليمني بمتابعة وتصفح مواقع الصحافة الإكترونية؟ r. إلى أي مدي تثكل الصحافة الإكترونية تهديداً قوياً لاستمرارية الصحف الورقية اليومية؟ r. ما الدوافع التي تجعل القراء يحرصون على متابعة الصحف الورقية والصحافة الإكترونية؟

؛. ـ ما القضايا والمواضيع التي تركز عليها الصحف الورقية ومواقع الصحافة الإكترونية؟

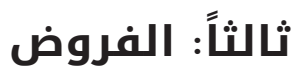
• هــاك علاقـة إيجابيـة بين حاجة القـراء لمتابعة الصحف الورقية من اسـتمرار صدورها، و متابعتهـم لمواقع الصحافـة الإلكترونية؛ • توجـد علاقة سـبيية بين ازدياد الحاجـة للصحف الورقية والمتغيـرات الحاصلة على الواقع

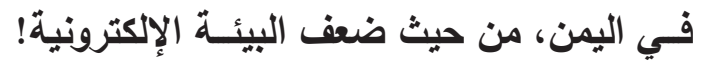
رابعاً: أهداف البحث

يـهدف هــا البحث السى معرفة مـدى مقروئية الصحـف الورقية اليومية، في ظل منافسـة

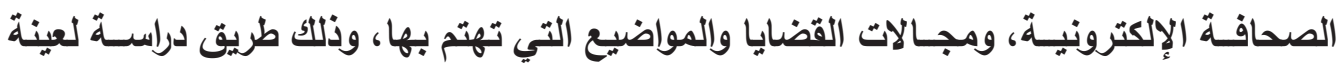

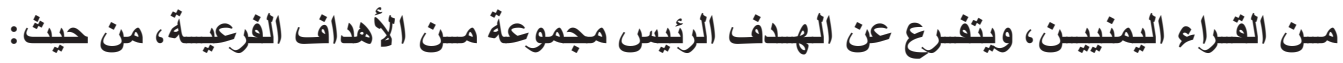
ا ـ معرفـة مـــى اهتمـام الجمهـور اليمني بمتابعـة الصحف الورقيـة اليوميـة وتصفح مواقع الصحافـة الإكترونية.

r. معرفة مدى تثـكيل الصحافة الإكترونية تهـيداً قوياً لاستمرارية الصحف الورقية اليومية. r. معرفة الدوافع التي تجعل القراء يحرصون على متابعة الصحف الورقية والصحافة الإكترونية. ع. . معرفة طبيعة القضاياوالمواضيع التيتركز عليها الصحف الورقيةومواقع الصحافة الإكترونية. خامساً: مجال البحث: يقتصـر مجـال هــا البحث على مـدى مقروئيـة الصحف اليمنيـة اليومية الورقيـة مقارنة

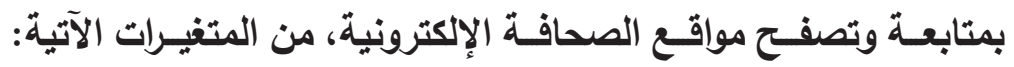
أ- الحـدود الزمانيـة: تمثلـت بالمـدة التي شـهـت فيها اليمـن متغيرات إعلامية وسياسـية بعد

\begin{tabular}{l|c} 
& مجلة الباحث الاعلامي| العدد ( r ) )
\end{tabular}




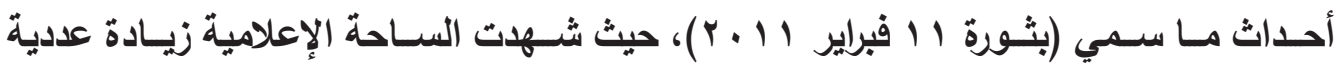
فـي الصحف الورقيـة اليومية الأهلية وفي مواقع الصحافـة الإكترونية.

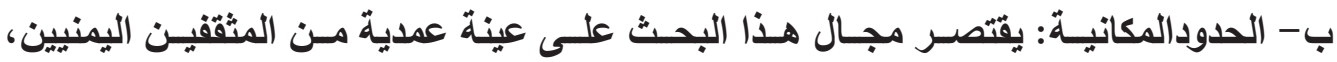

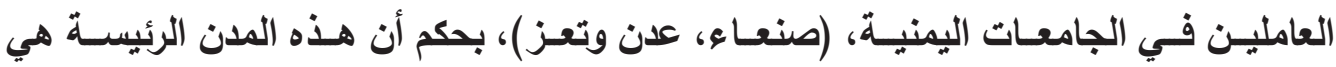

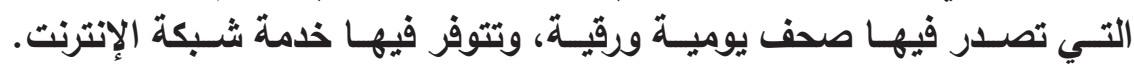

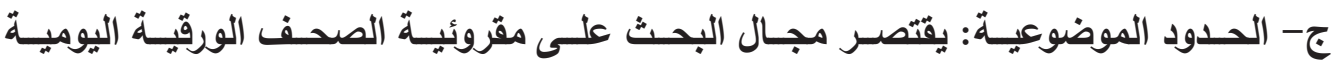

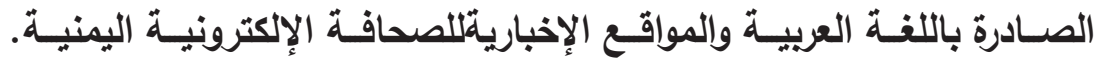

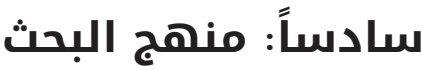

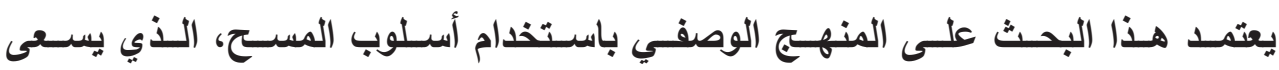

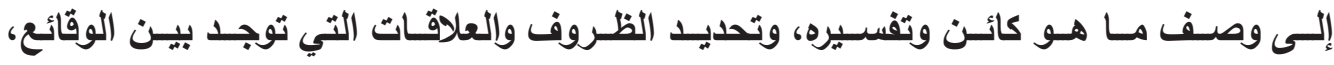

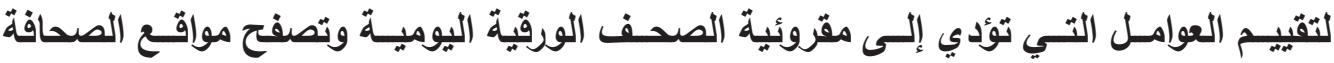

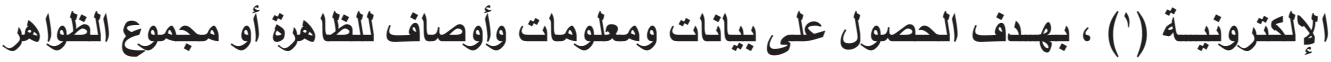

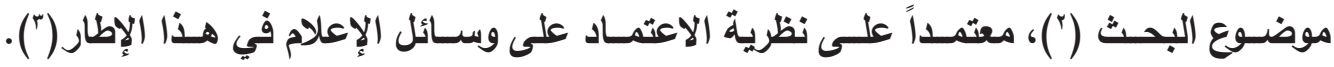

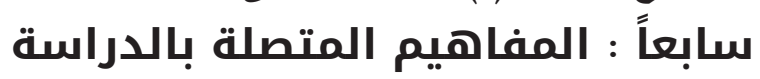

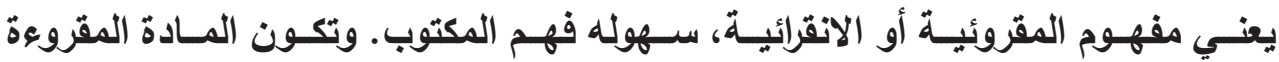

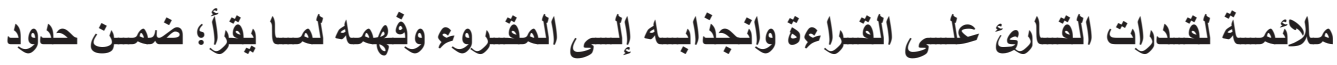

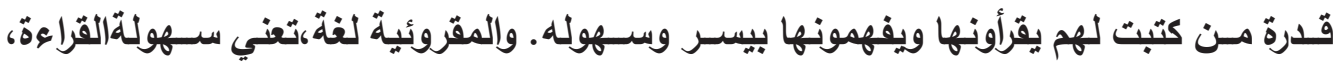

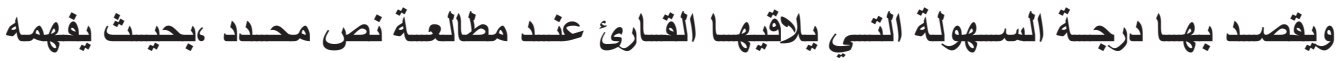

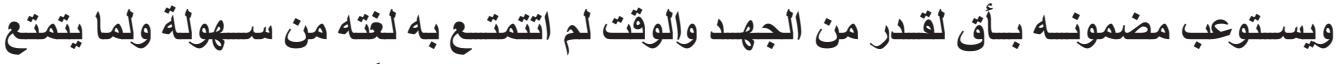

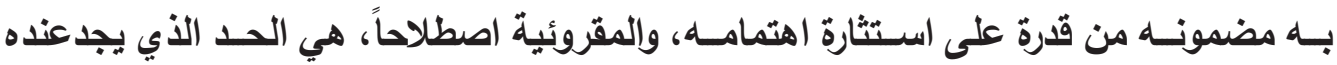

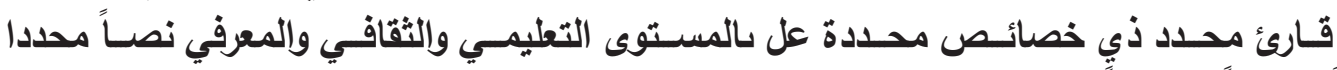

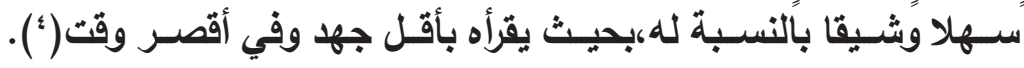

\section{الصحافة الإلكترونية}

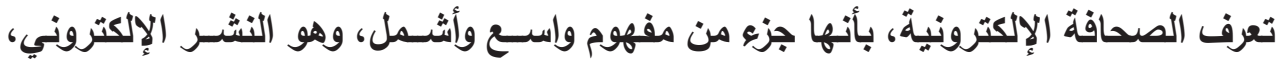

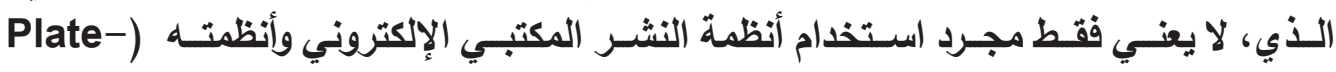

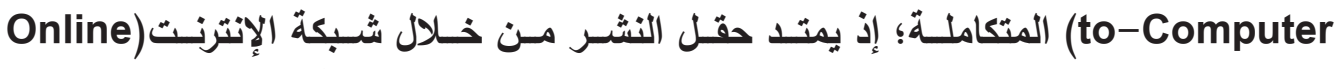

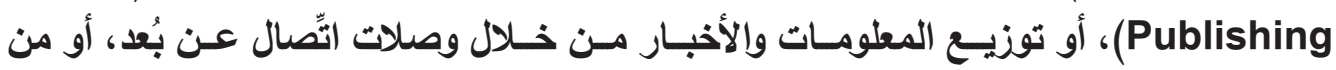

\begin{tabular}{l|c} 
& مجلة الباحث الاعلامي| \\
\hline 171 & العدد (r (r )
\end{tabular}


خلال الوسبائط المتعددة(Multimedia)، وغيرها من النُّم الاتصالية التي تعتمد على شـبكة

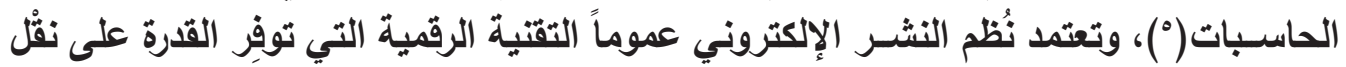

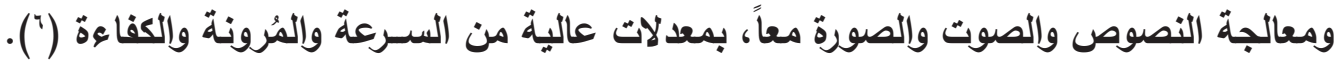

\section{الصحف الورقية والمواقع الإلكترونية اليمنية أولاً: الصحف الورقية اليومية الحكومية}

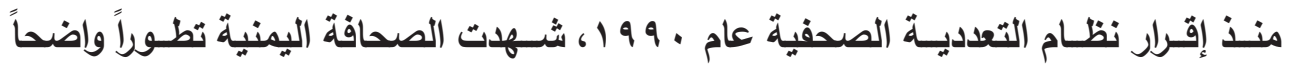

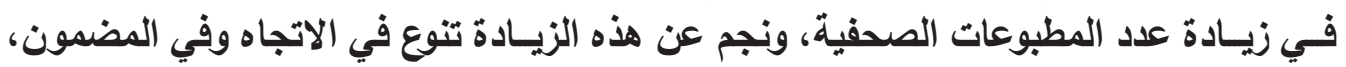

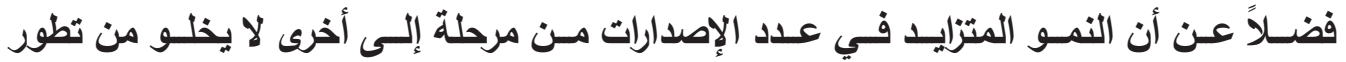

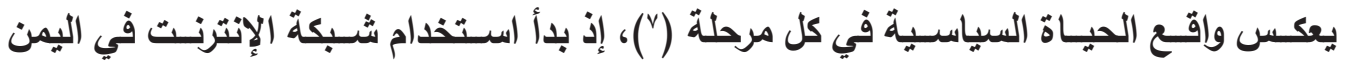

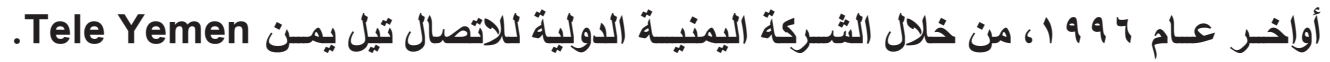

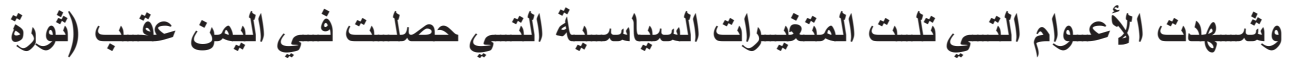

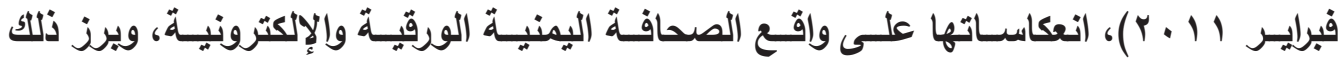

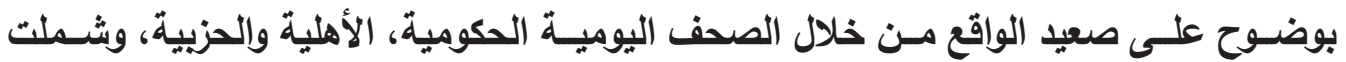

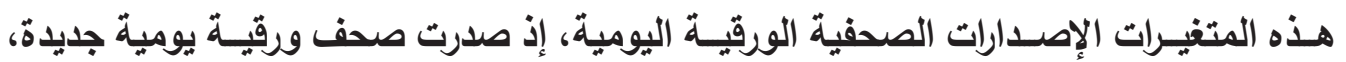

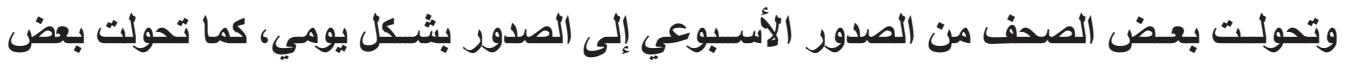

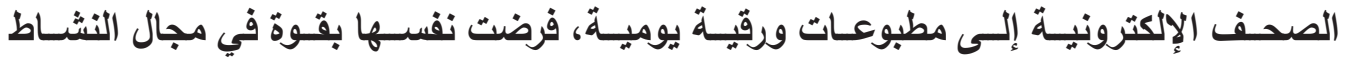

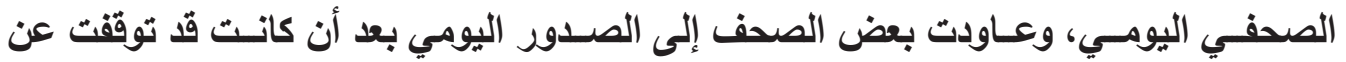

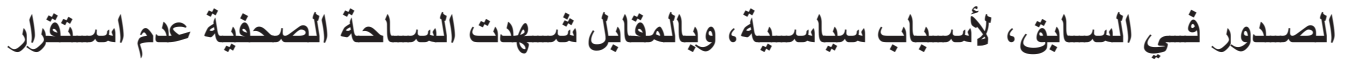

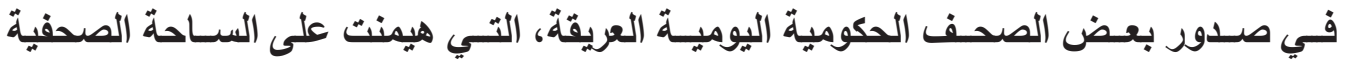

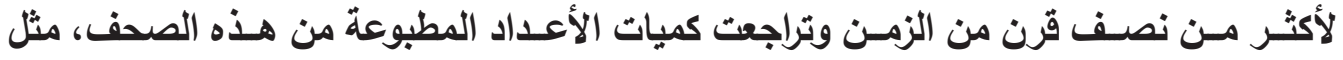

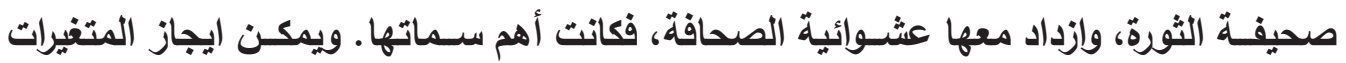

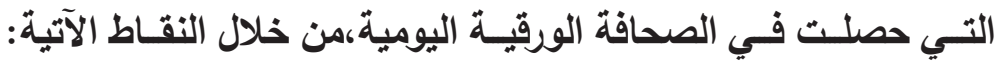
1. إن الصحافة الورقية اليومية الحكومية شهدت تراجعاً في إعدادها والكميات المطبوعة منها. r. شهدت الصحافة الورقية اليومية الأهلية وإلحزبية زيادة عددية في عدد الإصدارات.

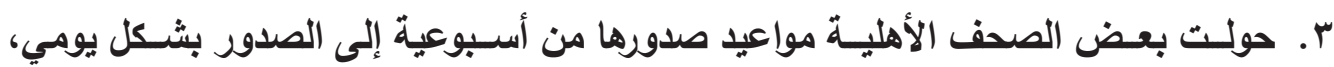
مثل صحسف: الأيام، الشـارع، المصدر والأمناء.

؛. هـــاك مواقـع صحفيـة إلكترونية تحولـت إلى إصدار صحسف ورقية، تصدر بشـكل يومي،

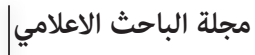


مثـل موقعس مأرب برس وعـدن الغد.

هـ تواجـه الصحافـة الورقيـة اليومية تحدمحدودية انتثـارها فـي أرجاء الوطن، وهذا بدوره

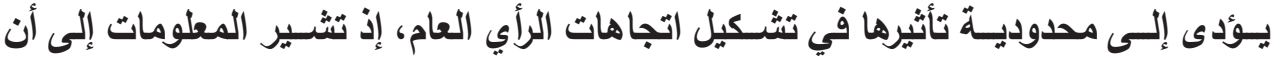

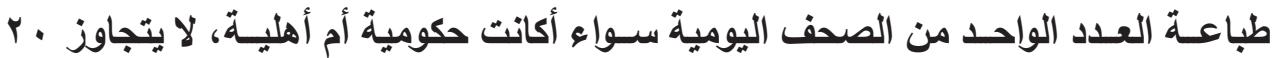

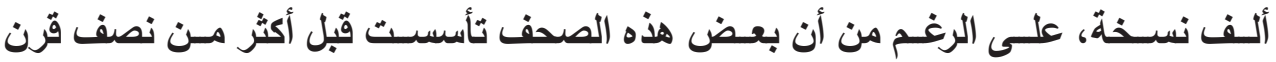

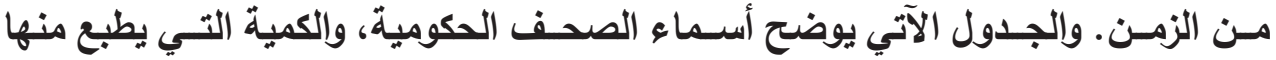
العدد الواحد، وأماكن صدورها.

\begin{tabular}{|c|c|c|c|c|}
\hline \multicolumn{5}{|c|}{ الصحف اليومية الحكومية والكمية التي يطبع منها العدد الواحد } \\
\hline كمية الطباعة & مكان الصدور & تاريخ التأسيس & اسم الصحفية & ت \\
\hline r. ألف r. & صنعاء & P199r & الثورة & -1 \\
\hline . 1 آلاف & تعز & $197 \%$ & الجمهورية & $-Y$ \\
\hline . 1 الانف & عدن & 1971 & ع 1 أكتوبر & $-\mu$ \\
\hline . 1الاف & (توققت عن الصدور) & $r \cdot r$ & السياسية & $-\varepsilon$ \\
\hline • • ألف & & المجموع & & \\
\hline
\end{tabular}

\section{ثانياً: الصحف الورقية اليومية الأهلية والحزبية:}

أمـا النـوع الثانـي من الصحف، هـو الصحف الورقيـة اليومية الأهلية والحزبية، إذ تثـير

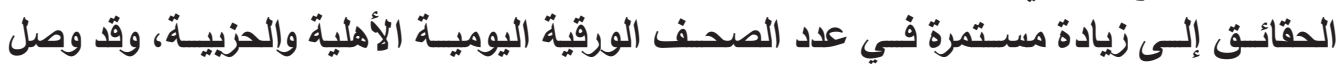

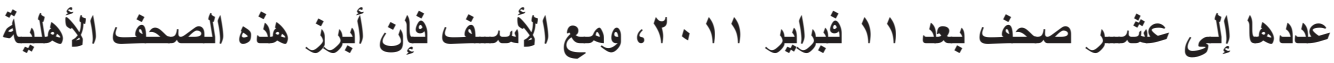

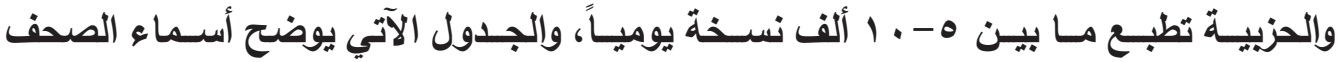

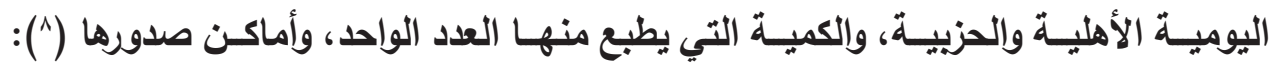

الصحف اليمنية اليومية الأهلية والحزبية والكمية التي يطبع منها العدد الواحد

\begin{tabular}{|c|c|c|c|c|}
\hline مكان الصدور & كمية الطباعة & تاريخ التأسبس & اسم الصحفية & التسلسل \\
\hline عدن & • 1 ألف & p)99. & الأيام & -1 \\
\hline صنعاء & . 1 آلاف & $r \ldots 1$ & الأولي & $-r$ \\
\hline صنعاء & . 1 آلاف & $r \ldots r$ & أخبار اليوم & r \\
\hline صنعاء & . 1 آلاف & $r \ldots r$ & اليمن اليوم & $-\varepsilon$ \\
\hline صنعاء & . 1 ألف & $r . . v$ & الشـارع & -0 \\
\hline صنعاء & ـ 1 ألف & $r . . v$ & المصدر & -7 \\
\hline
\end{tabular}




\begin{tabular}{|c|c|c|c|c|}
\hline عدن & 1 ألف & $r .1 Y$ & عدن الغذ & $-v$ \\
\hline صنعاء & ـ 1 ألف & $r .1 r$ & مأرب برس & $-\wedge$ \\
\hline عدن & ד آلاف & $r \cdot 1$. & الأمناء & -9 \\
\hline \multirow[t]{2}{*}{ صنعاء } & ه آلف & 2014 & صدى المسبرة & -1 . \\
\hline & १ 9 ألف نسخة & \multicolumn{3}{|c|}{ المجموع } \\
\hline
\end{tabular}

على الرغــم من التباين في وجهات النظر حـول صدور الصحف بهذا التنوع في الاتجاهات

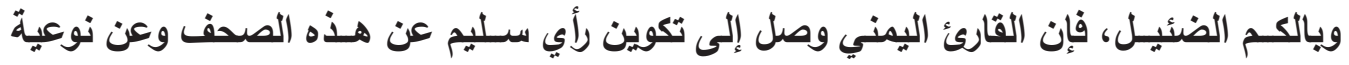

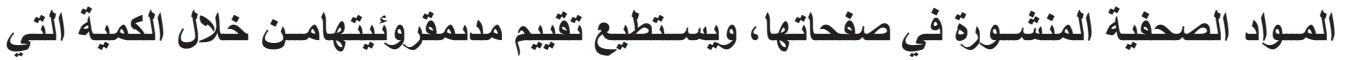

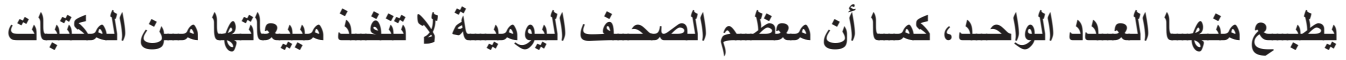

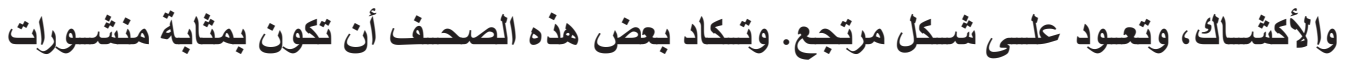

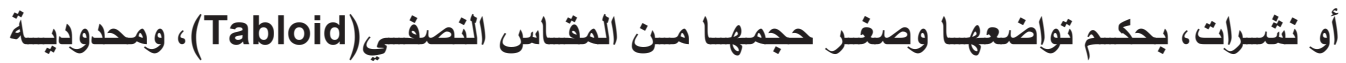
صفحاتها، وضعف إخراجها.

\section{ثالثاً: مواقع الصحافة الإلكترونية اليمنية}

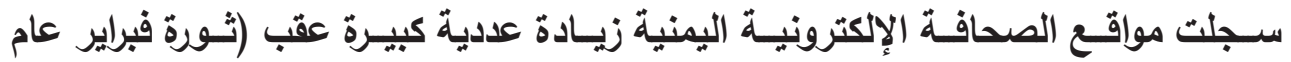

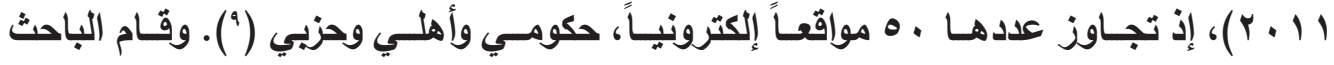

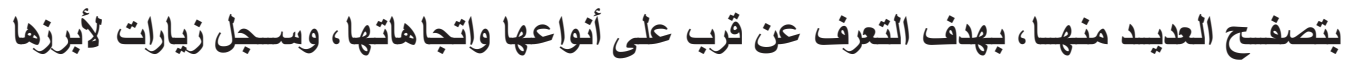

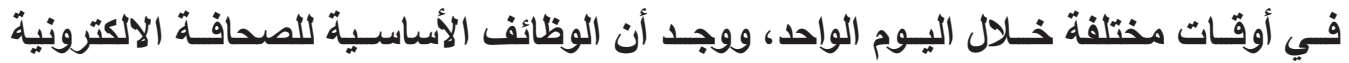

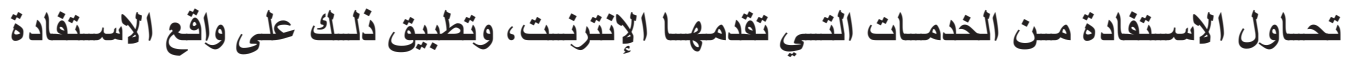

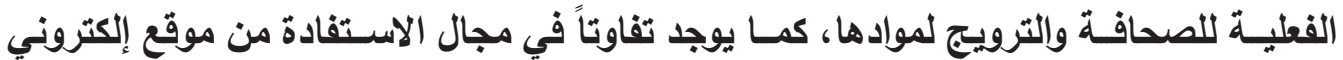

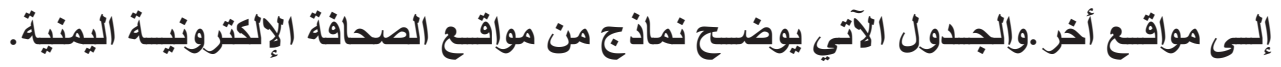

\begin{tabular}{|c|c|c|c|}
\hline \multicolumn{4}{|c|}{ نماذج من مواقع الصحافة الإكترونية اليمنية } \\
\hline الاتجاه & تاريخ التأسيس & اسم الوقع الإكترونى & التسلسل \\
\hline حزبي & $e^{r} \ldots 1$ & الاشتَراكي نت & -1 \\
\hline حزبي & $r \ldots r$ & المؤتمر نت & $-\overline{-r}$ \\
\hline حكومي & 2003 & الثَّرة نت & $-r$ \\
\hline حكومي & Y... & الجمهورية نت & $\overline{-\varepsilon}$ \\
\hline حزبي & $r \ldots \varepsilon$ & الوحدوي نت & -0 \\
\hline حكومي & $r \ldots q$ & سبتمبر نت & -7 \\
\hline أهلى & $r \ldots q$ & مأرب برس & $-V$ \\
\hline أهلي & $T \ldots q$ & المصدر أونلاين & $\overline{-\Lambda}$ \\
\hline
\end{tabular}

مجلة الباحث الاعلامي| 


\begin{tabular}{|c|c|c|c|}
\hline أهلي & $r \ldots r$ & نبأ نيوز & -9 \\
\hline أهلي & $r \ldots v$ & التغيير نت & -1 . \\
\hline حزبي & $r \cdot 1$. & الصحو نت & -11 \\
\hline حكومي & $r+11$ & سبأنت & -12 \\
\hline أهلي & 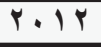 & عدن الغذ & -13 \\
\hline أهلي & $r .1 T$ & هنا عدن & -14 \\
\hline أهلي & $r .1 r$ & الرأي برس & -15 \\
\hline
\end{tabular}

ويمكن تقسيم مواقع الصحافة الإلكترونية اليمنية إلى الأتي: • مواقع إلكترونية ترتبط وتتبع صحف ورقية: وتقوم بنشـر ما تنشـره الصحفية الورقية، كما

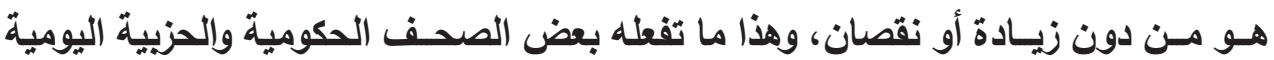

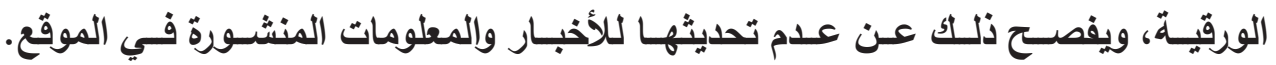

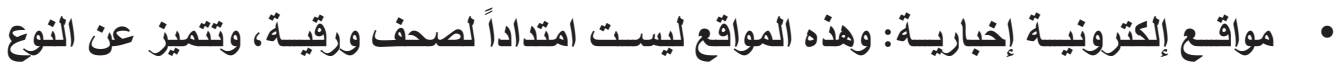

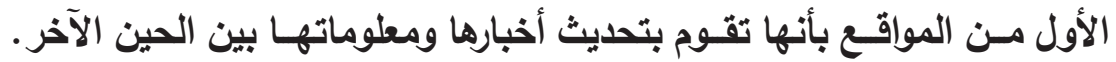

\section{ا-المواقع الإلكترونية الأهلية}

مواقع الصحافة الإلكترونية الأهلية لا تفصح عن اتجاهها السياسـي، وتهتم بشــل رئيس

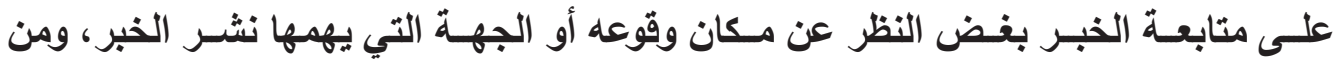

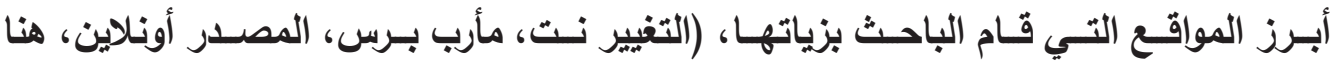

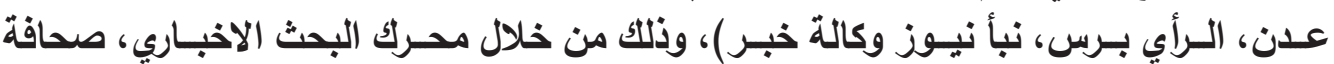

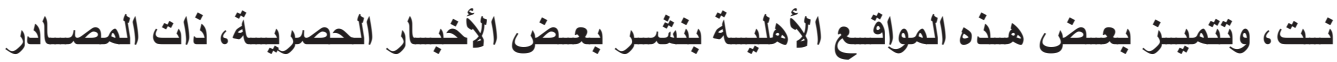

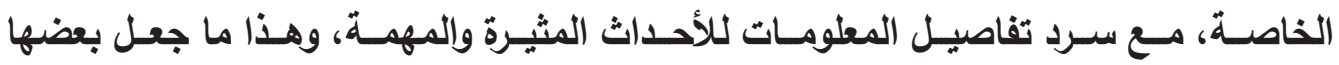

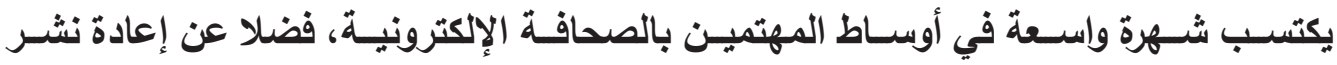
بعـض الأخبـار اليمنيـة المنقولــة من مواقـع أو صحف عربيـة والمتصلة بالشـأن المحلي.

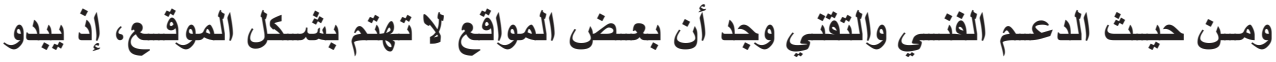

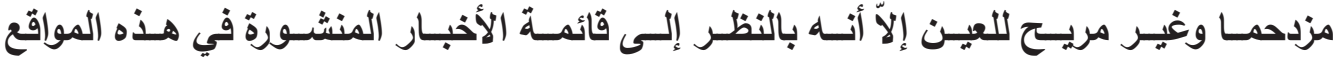

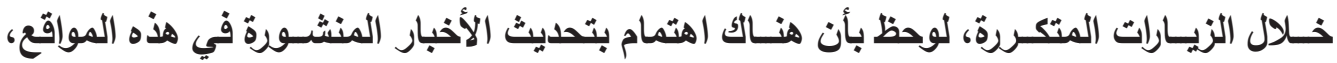

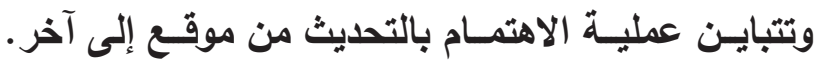

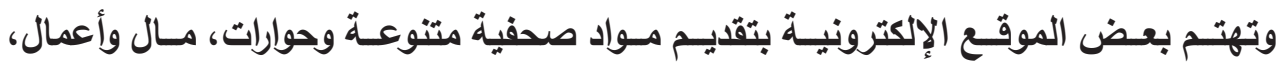

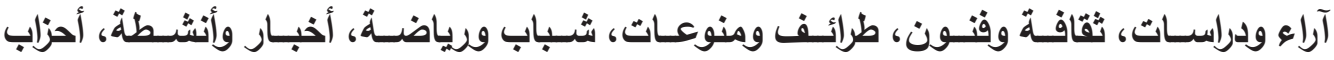

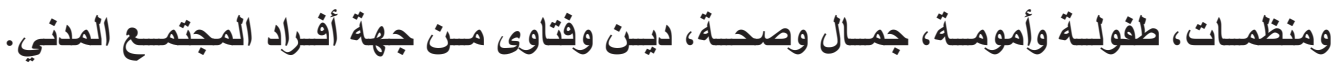
\begin{tabular}{l|l} 
& مجلة الباحث الاعلامي \\
\hline IVT & العدد (r )
\end{tabular} 


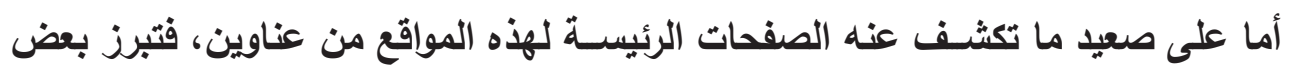

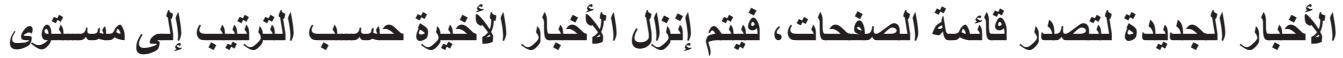

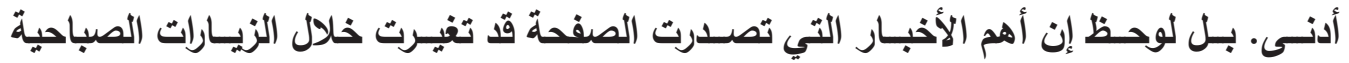

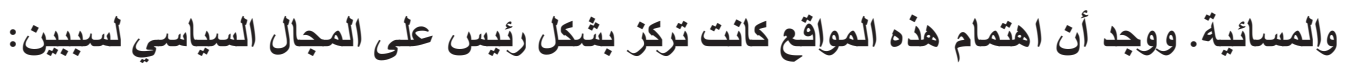

الأول: الحرالك السياسي النشط، والأحداث التي تعيشها اليمن عقب ثورة فبراير 11. ب.

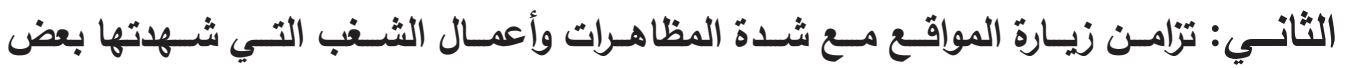

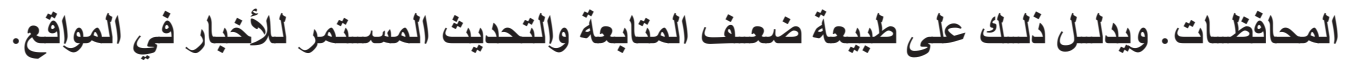

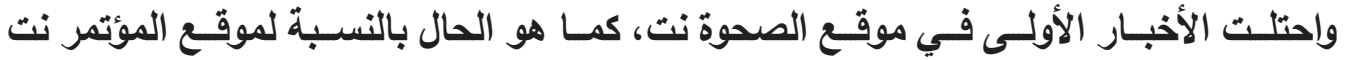

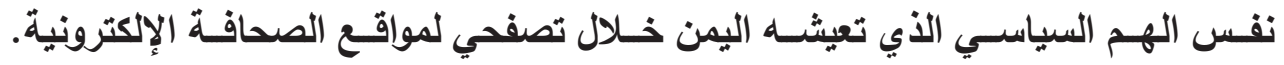

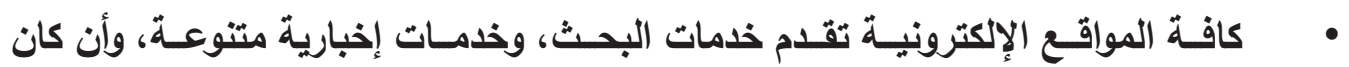

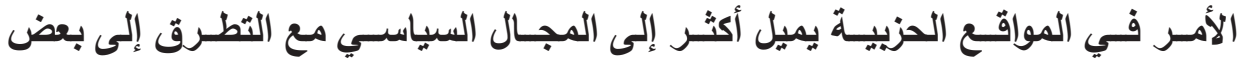

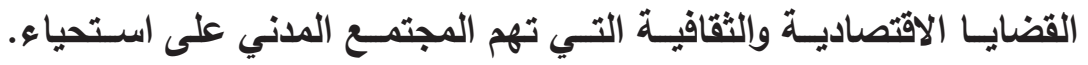

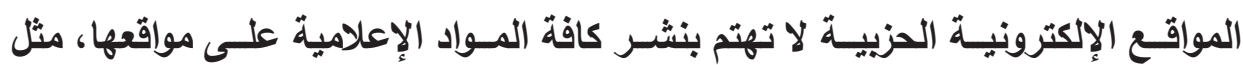

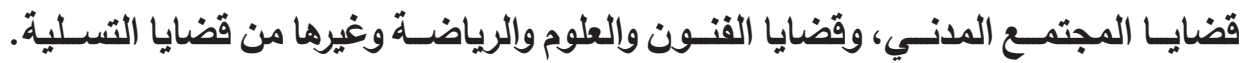

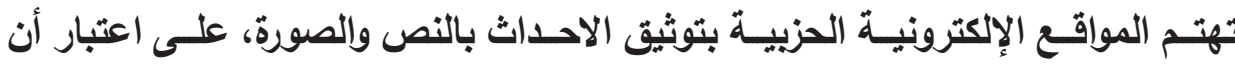
مـا تقدمـه الصـورة من إخبار هـي واقعية.

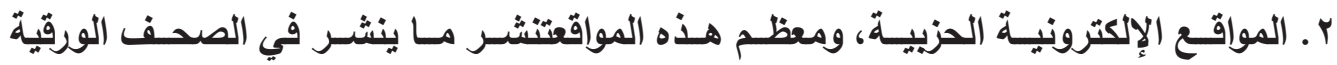

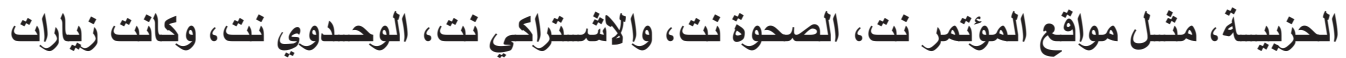

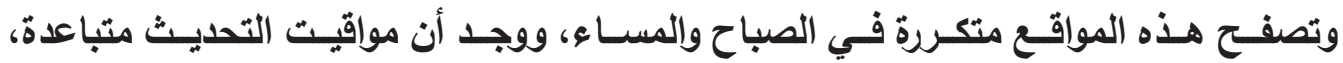

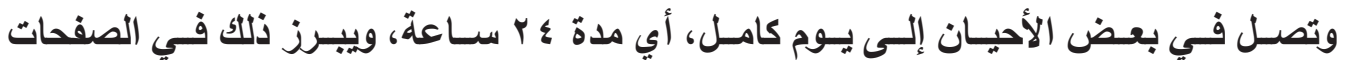
الرئيسـة لتبلك المواقع.

ب. مواقـع الصحـف الورقيـة اليوميـة: مواقع الصحف اليوميـة على الإنترنت، هـي امتـاد لما

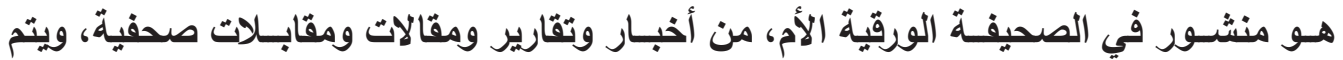

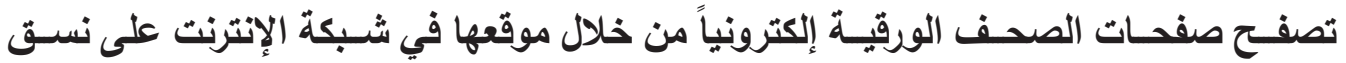

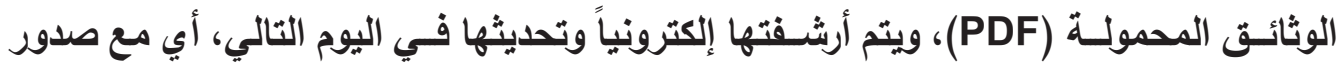
العدد الجديـــ من الصحيفة. ومسن بيـن أسـباب تلنسي الإقبال على تصفـح ومتابعـة الصحافـة الإكترونية فـي اليمن 
الانقطاعـات المتكـررة للتيـار الكهريائي، والذي يصل في بعض الأحيان إلى بإ ا سـاعة يومياً،

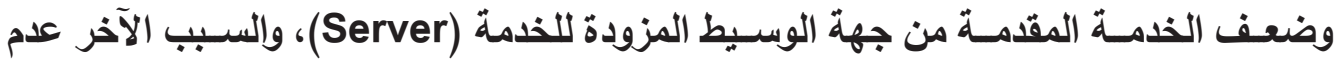

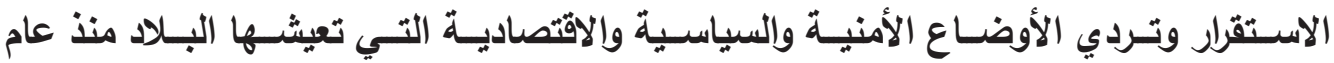

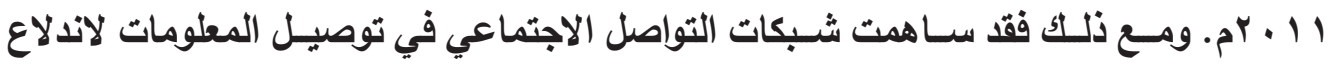

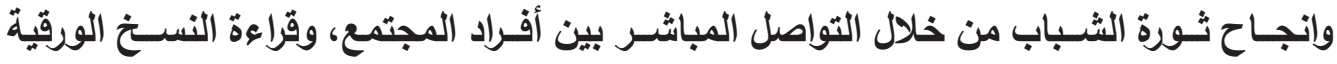
والإلكترونية على الثـبكة (').

\section{نتائج الدراسة الميدانية للصحف الورقية والإلكترونية أولاً: مجتمع الدراسة الميدانية وعينتها:} بهدف تنفيذ الدراسة الميانية قام الباحث بتصميم استبيان، وتم عرضه على مجموعة من منآن

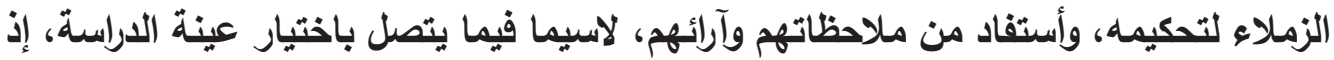

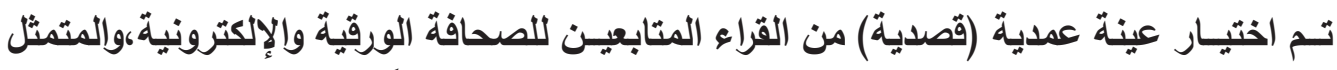

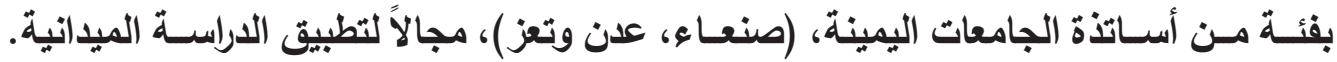

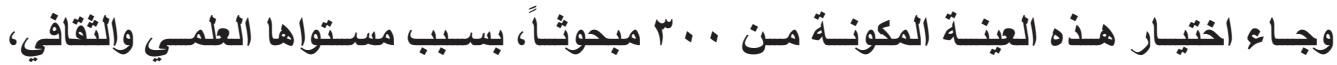

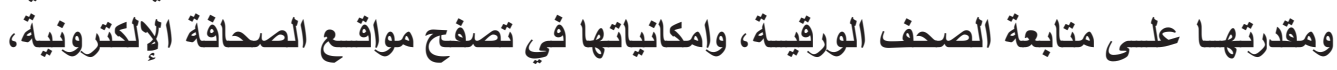

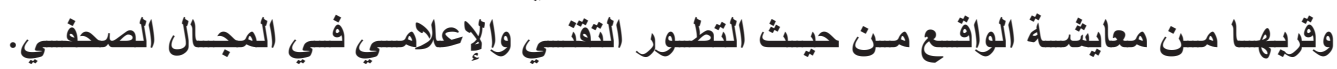

\section{ثانياً: بيانات المبحوثين عينة الدراسة:}

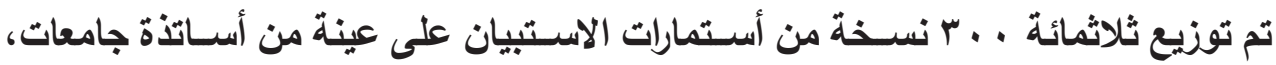

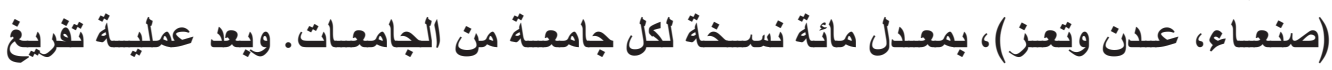

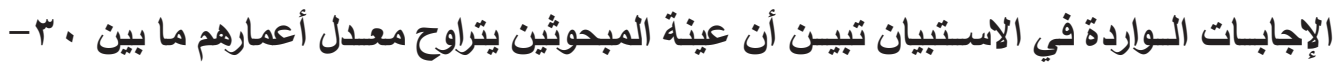

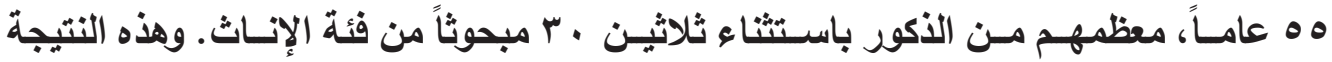

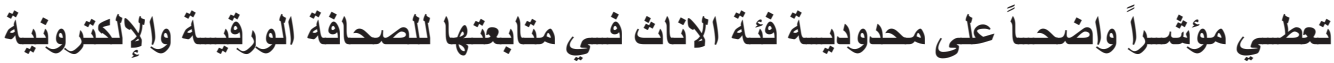
في المجتــع اليمني.الجدول رقـم (1 ) يوضـح توزيع المؤهـلات العلمية للمبحوثين.

\begin{tabular}{|c|c|c|}
\hline النسبة المئوية & العدد & المؤهل العلمي للمبحوثُن \\
\hline $4 \%$ & Tr & دبلوم عالي \\
\hline$\%$. & 7. & ماجستير \\
\hline$\% \vee 4$ & YYA & دكتوراه \\
\hline$\% 1 \ldots$ & $\mu \ldots$ & المجموع \\
\hline
\end{tabular}

ويمكـن أن تقــام النسـبة المرتفعـة من المبحوثيـن الحاصلين على مؤهلات عليا مؤثــرات 


\section{علميـة رصينة تخدم نتائج الاراســة.}

ثالثاً: مقروئية الصحف الورقيـة اليوميـة وتصفح مواقع الصحافـة الإلكترونيـة الجدول رقم (ץ) يبين الهتمام عينة الدراسـة بقراعة الصحف الورقية والصدافة الإلكترونية.

\begin{tabular}{|c|c|c|c|c|c|c|}
\hline \multicolumn{2}{|c|}{$y$} & \multicolumn{2}{|c|}{ أحياناً } & \multicolumn{2}{|c|}{ دائماً } & هل تقرأ الصحف الورقية \\
\hline النسبة & التكرارات & النسبة & التكرارات & النسبة & التكرارات & اليومية أم المواقع الإكترونية؟ \\
\hline$\% 0$. & 1. & $\% £ V$ & $\varepsilon 7$ & $\% r r$ & $0 \wedge$ & الصحف الورقية اليومية \\
\hline$\%$. & $\varepsilon$ & $\%$ & $r$. & $\% \mathrm{HV}$ & 71 & مواقع الصحافة الأكترونية \\
\hline$\%$ & 7 & $\% r r$ & Yr & $\%$ & 07 & الصحف الورقية والإكترونية \\
\hline$\% 1 \ldots$ & $r \cdot$ & $\% 1 \ldots$ & $9 \wedge$ & $\% 1 \ldots$ & IAY & المجموع \\
\hline
\end{tabular}

\section{تدل نتائج الجدول رقم (r) إلى الآتي:}

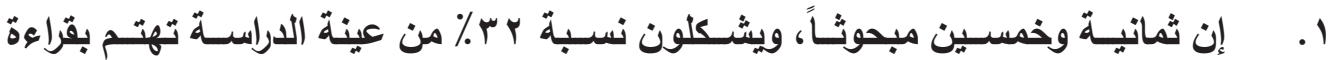

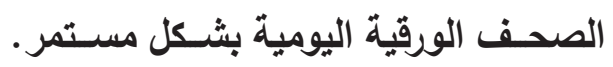

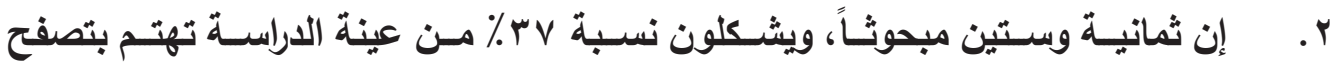

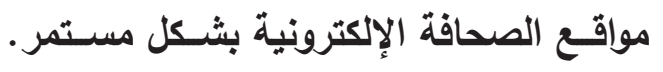

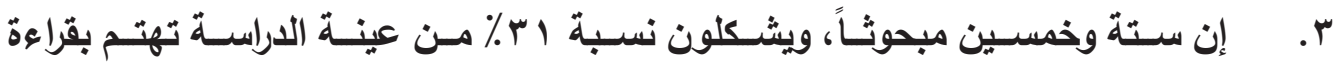

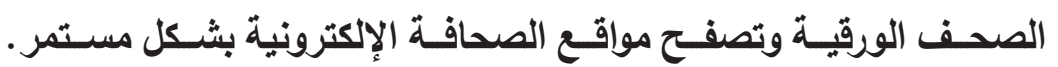

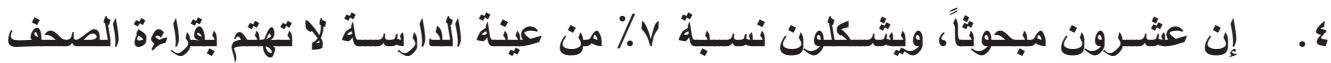

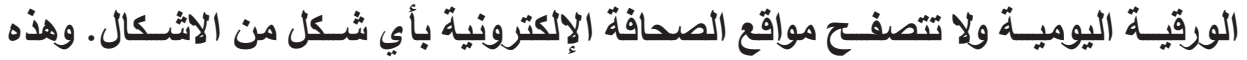

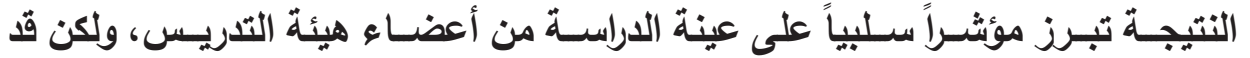

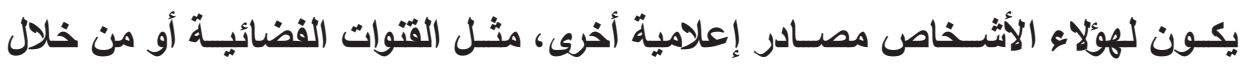
الرسـائل النصية للهواتف الأكية الأكية.

رابعاً: نوعية الصحف الورقية اليومية التي تفضل عينة الدراسة قراءتها

\begin{tabular}{|c|c|c|c|c|c|c|}
\hline \multicolumn{2}{|c|}{ V } & \multicolumn{2}{|c|}{ أحياناً } & \multicolumn{2}{|c|}{ دائماً } & مـــا نوعيــة الصحـف الورقيـة \\
\hline النسبة: & التكرارات & النسبةة & التكر ارات & النسبة & التكرارات & اليوميـة اليمنيـة التـي تفضلها؟ \\
\hline$\%$ & 7 & $\% \varepsilon$ & r. & $\% r r$ & $r \wedge$ & الحكومية \\
\hline$\% 1 \mathrm{~V}$ & Y & $\%$ \% & ir & $\% \leqslant 1$ & rs & الأهلية \\
\hline$\% r$ & $\varepsilon$ & $\%$ & $1 \varepsilon$ & $\%$ \% & YY & الحزبية \\
\hline$\% 1 \ldots$ & ir & $\% 1 \ldots$ & $\leqslant 7$ & $\% 1 \ldots$ & $\Lambda \varepsilon$ & المجموع \\
\hline
\end{tabular}
الجدول رقّم (ץ) يبيـن ذوعية الصدف الورقيـة اليومية التي تفضل عينة الدراسـة قراعتها.

مجلة الباحث الاعلامي| 


\section{تدل نتائج الجدول رقم (ץ) إلى الآتي:}

1. إن ثمانية وعشـرين مبحوثاً ويشـكلون نسـبة بr\% من عينة الدراسـة، يفضلون قراءة

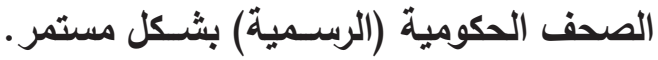

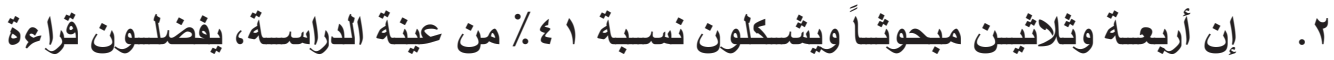

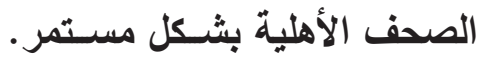

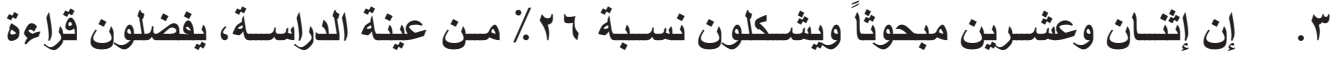

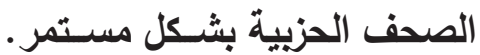
؛. أجاب إثنا عشـر مبحوثاً ويشـكون نسبة و ٪ من مجموع عينة الدراسة بأنهم لا يفضلون قراعة الصحف اليومية الحكومية ولا الصحف اليومية الأهلية ولا الصحف اليومية الحزبية. خامساً: المواقع الإلكترونية التي تحرص عينة الدراسة على تصفحها: الجدول رقـم ( ؛) بين ذوعية المواقع الإلكترونية التي تحرص عينة الدراسـة على تصفحها.

\begin{tabular}{|c|c|c|c|c|c|c|}
\hline \multicolumn{2}{|c|}{$\bar{y}$} & \multicolumn{2}{|c|}{ أحياناً } & \multicolumn{2}{|c|}{ دائما } & مــا مواقِع ع الصحافـة \\
\hline النسبة & التكرارات & النسبة & التكرارات & النسبة & التكرارات & 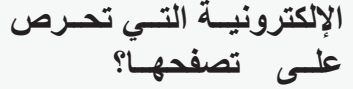 \\
\hline$\%$ & $\xi$ & $\% \uparrow \Lambda$ & $r$. & $27 \%$ & $\overline{Y 4}$ & الحكومية \\
\hline$\%$ ro & r & $\% Y v$ & $1 \leqslant$ & $\%$ \%q & $\varepsilon \Lambda$ & الأهلية \\
\hline$\%$ Y & $r$ & $\%$ & 11 & $\%$ \%ฯ & $\overline{r \varepsilon}$ & الحزبية \\
\hline$\% 1 \ldots$ & $\Lambda$ & $\% 1 \ldots$ & $O r$ & $\% 1 \ldots$ & 91 & المجموع \\
\hline
\end{tabular}

تدل نتائج الجدول رقم (ع) إلى الآتي:

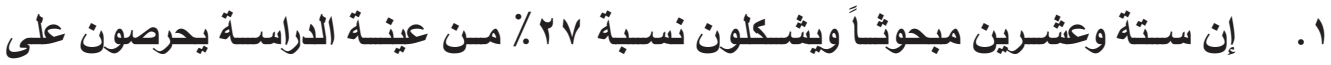

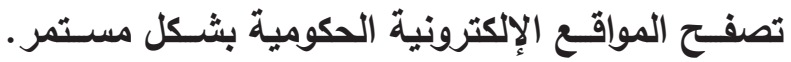

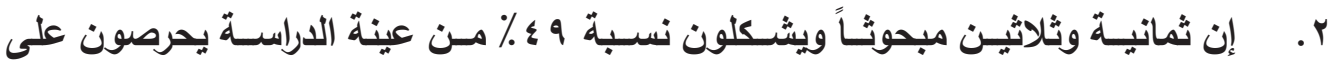

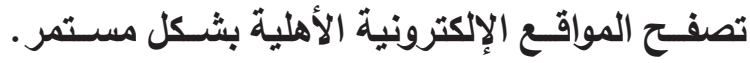

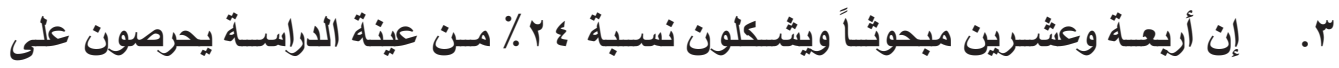

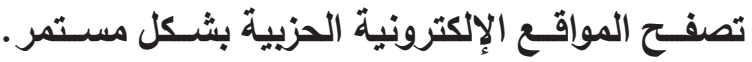
؛. إن ثمانية مبحوثين ويشكلون نسبة ه ٪ من مجموع عينة الاراسة لا يتصفحون المواقع

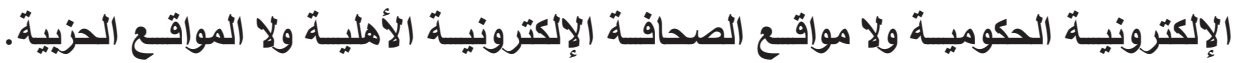


سادساً: الصحف اليوميـة الورقيـة التـي تفضل عينـة الدراسـة قراءتهـا الجدول رقـم (ه) يبيسن الصدف اليمنية اليومية الورقية التي تفضل عينة الدراسـة قراءتها.

\begin{tabular}{|c|c|c|c|}
\hline \multicolumn{4}{|c|}{ الصحف اليمنية اليومية التي تفضل عينة الدراسة قراعتها } \\
\hline الترتيب & 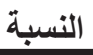 & التكرارات & اسم الصحيفة \\
\hline 5 & $\% \wedge$ & 22 & الثورة \\
\hline 6 & $\% v$ & $r$. & الجمهورية \\
\hline 9 & $\%$ & 18 & ع 1 أكتوبر \\
\hline 4 & $\% 9$ & $r \xi$ & 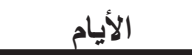 \\
\hline 5 & $\% \wedge$ & YY & أخبار اليوم \\
\hline 3 & $\% 9$ & Y & الثارع \\
\hline 2 & $\% 1$ & rA & المصدر \\
\hline 4 & $\% 9$ & Y $\varepsilon$ & 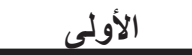 \\
\hline 5 & $\% \wedge$ & rr & اليمن اليوم \\
\hline 7 & $\% 4$ & 18 & عدن الغد \\
\hline 1 & $\% 11$ & 30 & 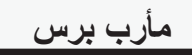 \\
\hline 8 & $\%$ & 18 & 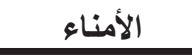 \\
\hline 10 & $\%$ & 10 & صدي المسيرة \\
\hline \multicolumn{2}{|c|}{$\% 1 \ldots$} & 280 & المجموع \\
\hline
\end{tabular}

\section{تدل نتائج الجدول رقم (•) إلى الآتي:}

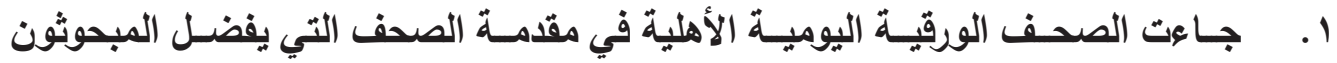

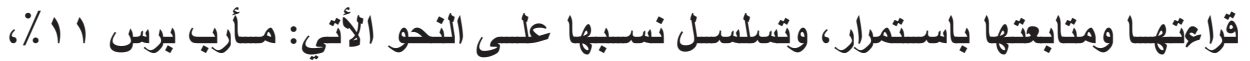

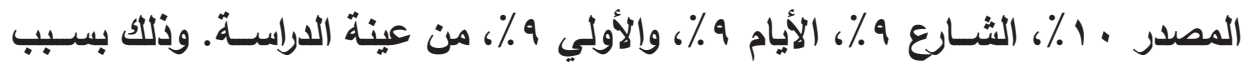

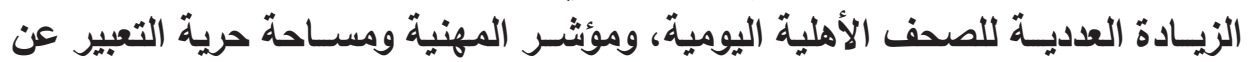
الـرأي في الصحـف الأهلية. r . فيمـا جـاء ترتيـب مقروئيـة الصحف الورقيـة اليوميـة الحكومية بعد الصحـف الأهلية،

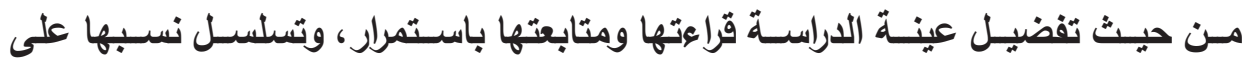

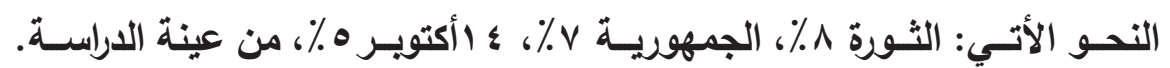


r. توزعت إجابات بقية المبحوثين ويثـكلون نسـبة ب ا ٪ من عينة الدراسـة، على تفضيل

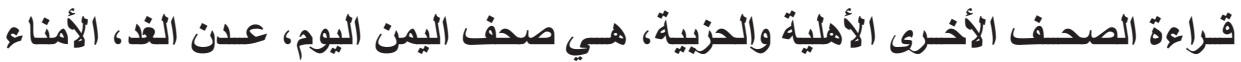

$$
\text { وصدى المسيرة. }
$$

سابعاً: المواقع الإلكترونية اليمنية التي تفضل عينة الدراسـة تصفحها جـدول رقـم (†) يبيـن توزيع إجابات عينة الدراسـة، بأســـاء المواقـع الإلكترونيـة اليمنية التـي تفضسل عينة الدراسـة تصفحهـا ومتابعتها، حسـب أهميتها:

\begin{tabular}{|c|c|c|c|}
\hline \multicolumn{4}{|c|}{ مواقع الصحافة الإكترّونية اليمنية التي تفضل عينة الدراسةً تصفحها } \\
\hline الترتيب & النسبة & التكرارات & 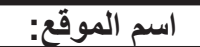 \\
\hline 9 & $\% \varepsilon$ & Tr & الثورة نت \\
\hline 8 & $\%$ & 17 & الجمهورية نت \\
\hline 11 & $\%$ & $1 \varepsilon$ & سبتمبر نت \\
\hline 10 & $\%$ & 17 & 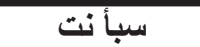 \\
\hline 2 & $\% 1$. & Y⿳ & التغيير نت \\
\hline 3 & $\% 9$ & rq & 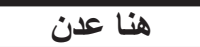 \\
\hline 6 & $\%$ & $\overline{Y Y}$ & المؤتمر نت \\
\hline 5 & $\% 9$ & $\overline{Y \varepsilon}$ & 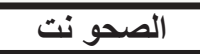 \\
\hline$\overline{7}$ & $\% \mathrm{~V}$ & $\overline{11}$ & الاششتر اكي نت \\
\hline 6 & $\% \mathrm{v}$ & 20 & 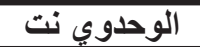 \\
\hline 1 & $\% 11$ & 30 & مأرب برس \\
\hline 2 & $\% 1 r$ & 32 & المصدر أونلاين \\
\hline 11 & $\%$ & 10 & الرأي برس \\
\hline 12 & $\% \varepsilon$ & 12 & مواقع أخرى \\
\hline \multicolumn{2}{|c|}{$\%$} & 280 & 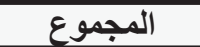 \\
\hline
\end{tabular}

\section{تدل نتائج الجدول رقم (†) إلى الآتي:}

ا. احتلـــ المواقـع الإكترونيـة الأهلية والحزيية مقدمة المواقع مـن حيث تفضيل تصفحها ومتابعتها بشكل مستمر من جهة المبحوثين، وتسلسل نسبها على النحو الأتي: المصدر

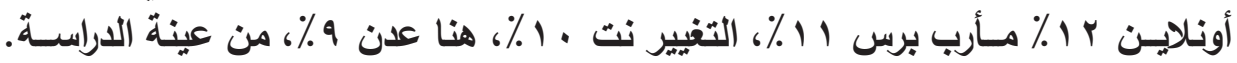

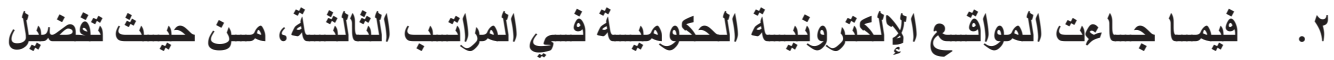

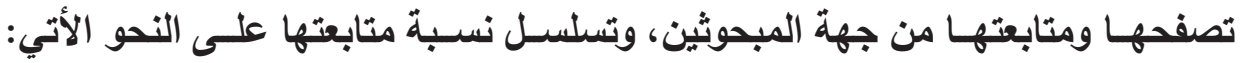

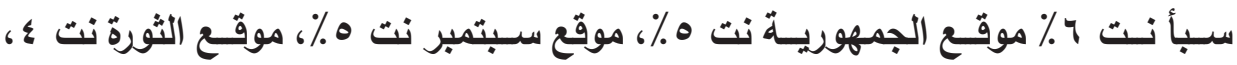
من عينة الدراسـة. r. توزعت إجابات أحد عشر مبحوثاً ويشكلون نسبة ؛ ٪ من عينة الاراسة، على تفضيلهم مجلة الباحث الاعلامي| 


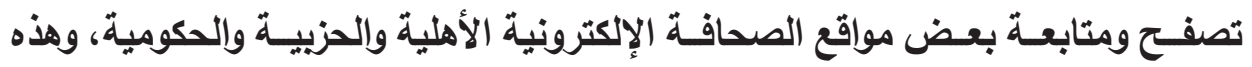

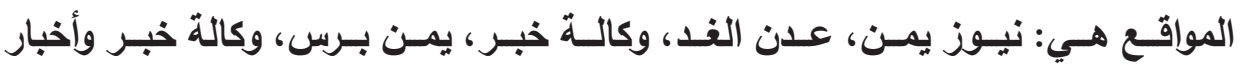

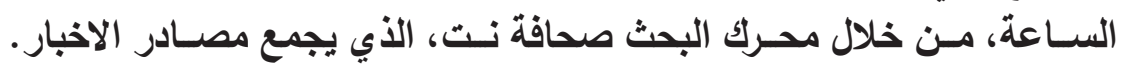

ثامناً: طبيعة المواقع التي تفضل عينة الدراسة تصفحها إلكترونياً: الجـول رقـم (V) يبيـن توزيـع إجابـات عينـة الدراسـة، عـن طبيعـة المواقع اليمذيـة التي تفضـل العينــة تصفحها.

\begin{tabular}{|c|c|c|c|}
\hline الترتيب & النسبة المئوية & التكرارات & إلكترونياً المواقع التي تفضل عينـة الدارسـة تصفحهـا \\
\hline$r$ & $\% 11$ & ○. & مواقع الصحف الورقية إلكترونياً \\
\hline 1 & $\%$ & $1 \ldots$ & المواقع الإخبارية \\
\hline$\varepsilon$ & $\% \wedge$ & $r \leqslant$ & مواقع المحطات الإذاعية \\
\hline 0 & $\%$ & 17 & مواقع القنوات التلفزيونية \\
\hline r & $\%$ \% & $\wedge$. & متابعة ما ينشر في شبكات التواصل الاجتماعي \\
\hline 9 & $\%$ & 1. & أسباب أخرى \\
\hline & $\% 1$. & r^. & 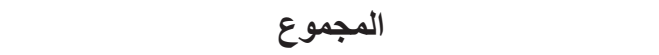 \\
\hline
\end{tabular}

تدل نتائج الجدول رقم (v) إلى الآتي:

1. يفضل مائة مبحوث ويشكلون نسبة جץ\% من عينة الاراسة، تصفح المواقع الإخبارية.

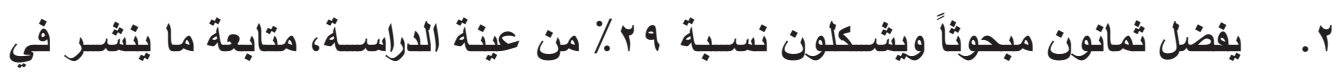
شـبكات التواصل الاجتماعي.

r. يفل خمسون مبحوثاً ويشكلون نسبة س 1 \% من العينة، تصفح الصحف الورقية إلكترونياً.

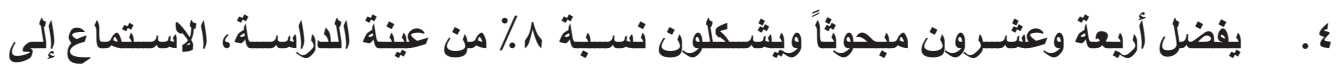
البـث الإذاعسي من خلال مواقع المحطـات الإذاعية.

هـ يفضل ستة عشر مبحوثاً ويشكلون نسبة ه \% من عينة الاراسة، مشا هدة القتوات التلفزيونية.

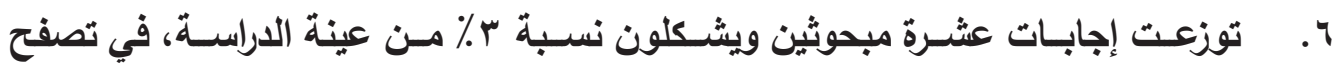

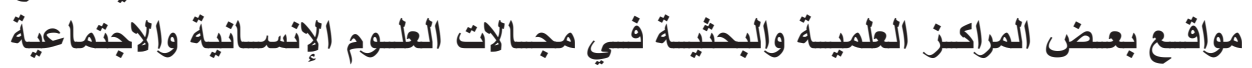




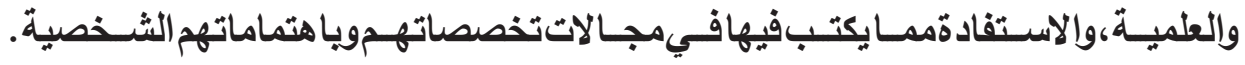

\section{تاسعاً: التحديات التي تواجه قراء ومتصفحي الصحافة الإلكترونية}

الجدول رقم (^) يبين التحديات التي تواجه قراء ومتصفحي الصدافة الإلكترونية في اليمن.

\begin{tabular}{|c|c|c|c|c|c|c|}
\hline \multicolumn{2}{|c|}{$\bar{y}$} & \multicolumn{2}{|c|}{ أحياناً } & \multicolumn{2}{|c|}{ دائماً } & 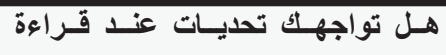 \\
\hline 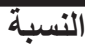 & التكرارات & النسبة: & الت التكرارات & النسبة & التكرارات & ـي ياحتُ عنها؟ \\
\hline$\% r v$ & $\overline{Y 4}$ & $\% \uparrow \wedge$ & $\overline{11}$ & $\% 11$ & YY & تحديات الصحف الورقية اليومية \\
\hline$\% \vee r$ & v. & $\% \vee r$ & 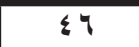 & \%^r & 91 & تحديات مواقع الصحافة الإكترونية \\
\hline 1. & 99 & 1. & $7 \varepsilon$ & 1. & $T$ & المجمو: \\
\hline
\end{tabular}

\section{تدل نتائج الجدول رقم (^) إلى الآتي:}

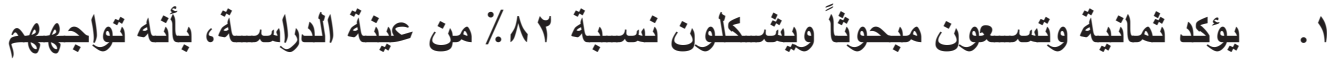
تحديات باسـتمرار عند تصفحهم لمواقِع الصحافة الإكترونية.

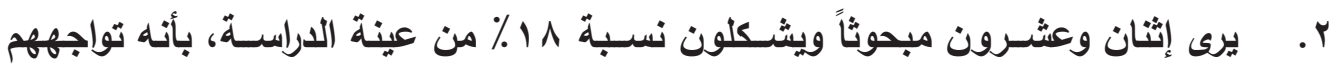

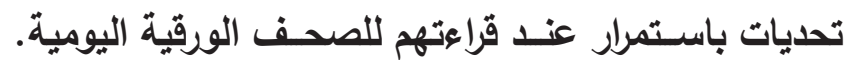

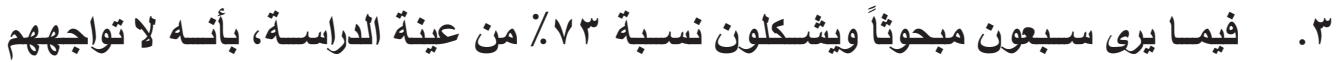

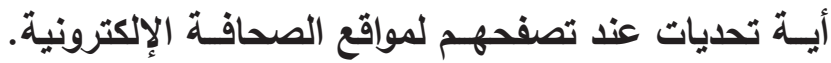

عاشراً:المواضيع التي تحرص عينة الدراسة على قراءتها في الصحف الورقية الصفية جـاول رقّم (9) يبيـن توزيـع إجابـات عينـة الدراسـة، عـن الدواضيـع التي تحـرص عينة

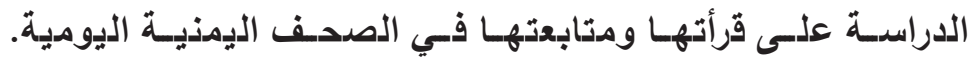

\begin{tabular}{|c|c|c|c|}
\hline الترتيب & النسبة المئوية & التكرارات & المواضيع التي تحرص عينة الدراسة على متابعتها \\
\hline 1 & $\%$ YV & v & الأخبار المحلية \\
\hline$\varepsilon$ & $12 \%$ & $r \varepsilon$ & الأخبار العربية \\
\hline - & $\% \wedge$ & rY & الأخبار والعالمية \\
\hline r & $\%$. & 09 & قراءة المقالات الصدفية \\
\hline$r$ & $14 \%$ & $\varepsilon$. & متابعة المقابلات الصحفية \\
\hline$r$ & $14 \%$ & $\varepsilon$. & متابعة التحقيقات الصحفية \\
\hline 7 & $\%$ & ir & متابعة الرسوم الكاريكاتيرية و الابراج و التسالي \\
\hline & $\% 1$. & rA. & المجموع - المو \\
\hline
\end{tabular}




\section{تدل نتائج الجدول رقم (9) على الآتي:}

1. احتلـت المتابعـة اليوميـة للأخبـار المحليـة المرتبـة الأولـي، مـن حيـث حـرص عينة

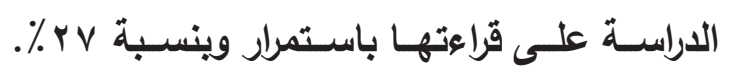

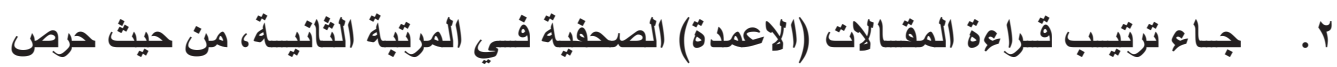

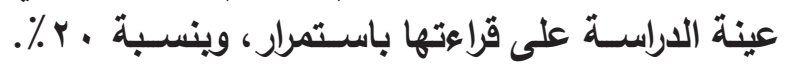

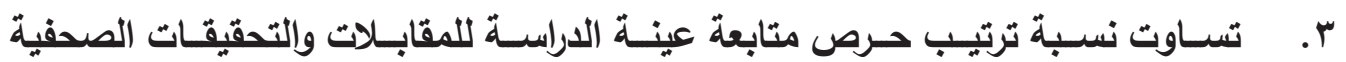

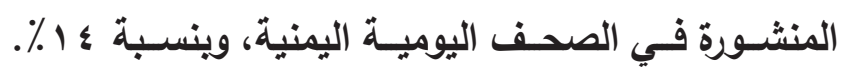
أحد عشر: تفضيل عينة الدراسة لتصفح مواقع الصنة، ولصحافة الإلكترونية: جدول رقم ( • ) يبين إجابات عينة الدراسة عن دوافع تفضيلهم لتصفح مواقع الصحافة الإلكترونية.

\begin{tabular}{|c|c|c|c|}
\hline الترتيب & 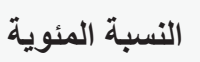 & التكرارات & دوافـع عينة الدراسـة لتصفح مواقع الصحافـة الإككترونية \\
\hline 1 & $\%$. & $\Lambda \varepsilon$ & مساحة الحرية فيها واسعة \\
\hline$r$ & $19 \%$ & or & تحديث الاخبار والمعلومات أولا بأول \\
\hline$r$ & $\%$ \% & 79 & تركز على الاختصار في نثر الأخبار والمعلومات \\
\hline 0 & $\% 11$ & rr & ليس لها ضوابط، وتتميز بالإثارة \\
\hline$\varepsilon$ & $9 \%$ & rq & تغطي بعض القضايـا التي لا تتطرق لهـا الصحف الورقية \\
\hline 9 & $7 \%$ & r. & لمو اكبـة التطور ات التقتيـة الحاصلة في المجـال الإعلامي \\
\hline & $\% 1 \ldots$ & rA. & المجموع \\
\hline
\end{tabular}

\section{تدل نتائج الجدول رقم (· (1) على الآتي:}

ا. ــرى عيـــة الدراسـة أن السـبب الأول الـــي يدفعها لتصفـح الصحافـة الإكترونية، هو

$$
\text { وجـود مسـاحة حرية واسـعة فيها. }
$$

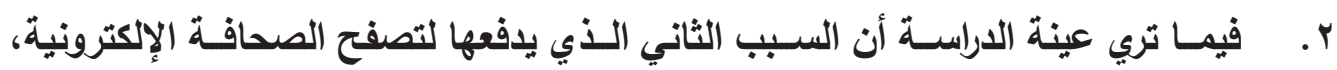

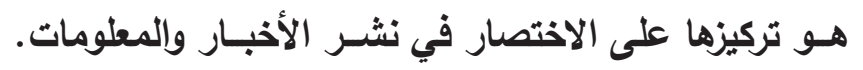

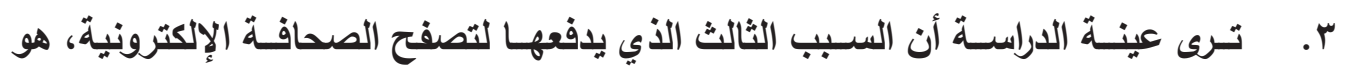
تحديثها للأخبار والمطلومـات أولاً بأول.

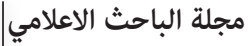


إثنا عشر: الصحافـة الإلكترونية وتهديدها لاستمرارية صدور الصحف الورقية: جـول رقـم (11) يبين توزيـع إجابات عينة الدراسـة، عن مدى تهديد الصدافـة الإلكترونية للصحف الورقية اليومية.

\begin{tabular}{|c|c|c|c|c|c|c|}
\hline \multicolumn{2}{|c|}{ ע } & \multicolumn{2}{|c|}{ إلى حداً ما } & \multicolumn{2}{|c|}{ نعم } & هـل تــرى أن الصحافـة \\
\hline النسبة & 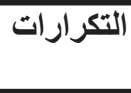 & النسبة & 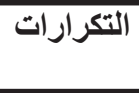 & النسبة & التكرارات & 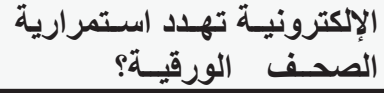 \\
\hline$\%$ \% & IY & $\%$ Y & 79 & \%rr & 9. & 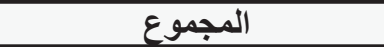 \\
\hline
\end{tabular}

تدل نتائج الجدول رقم (1/) على الآتي: 1. يؤكد تسعون مبحوثاً ويشكلون نسبة ب r ٪ من عينة الدراسة على أن الصحافة الإكترونية

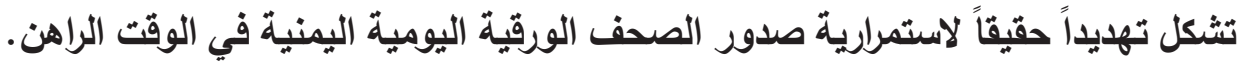

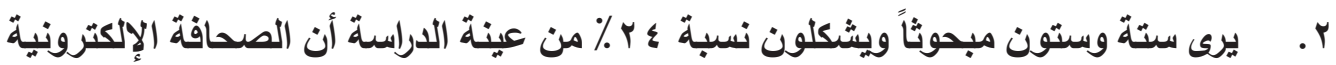

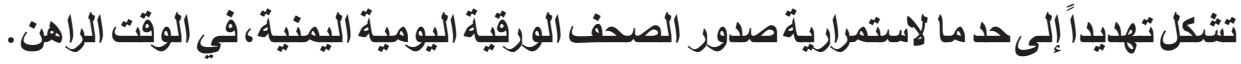

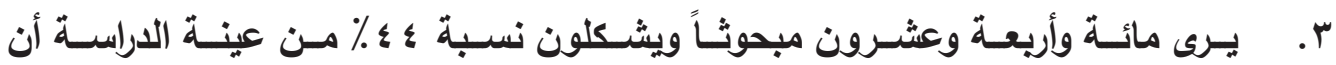

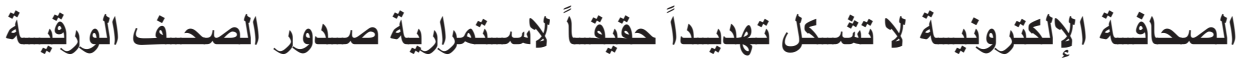

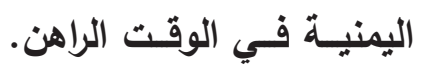

ثلاثة عشر: الصحافة الإلكترونية والدور الذي تؤديه الصحف الورقية:

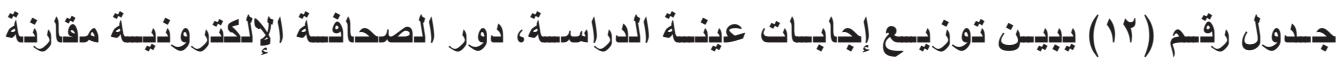

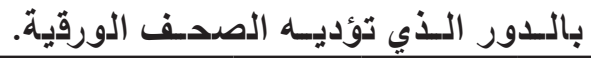

\begin{tabular}{|c|c|c|c|c|c|c|}
\hline \multicolumn{2}{|c|}{$\bar{y}$} & \multicolumn{2}{|c|}{ أحياناً } & \multicolumn{2}{|c|}{ نعم } & هل تصفح الصحافِة الإكترونيـة \\
\hline النسبة الن & التكرارات & النسبة & التكرارات & النسبة الن & التكرارات & 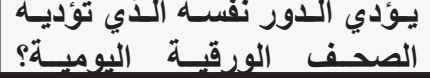 \\
\hline$\% \Psi \varepsilon$ & 97 & $\% \Gamma v$ & $1 . r$ & $\% r^{2}$ & $\overline{\lambda r}$ & المجموع \\
\hline
\end{tabular}
تدل نتائج الجدول رقم (r I) على الآتي:

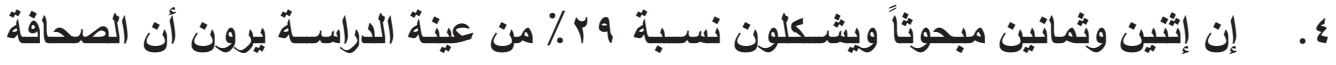

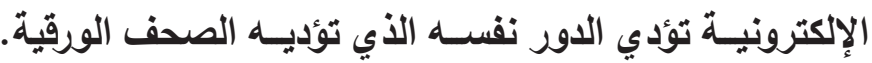

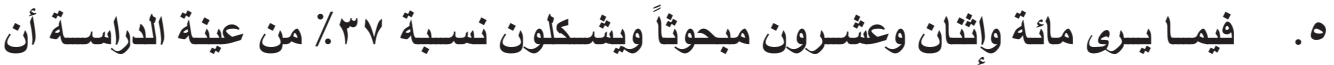

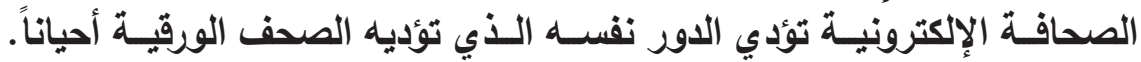

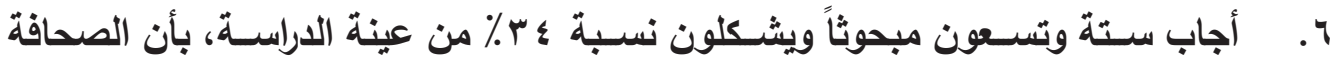

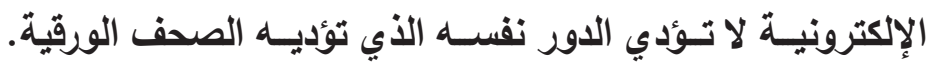


أربعة عشر: تحقق هذا الدور من خلال أي نوع من الصحافة:

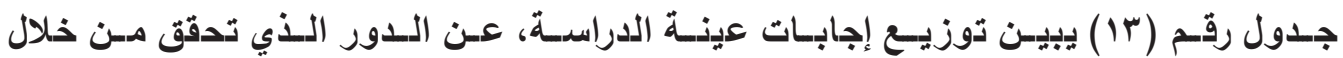

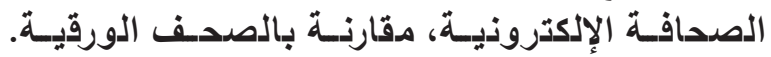

\begin{tabular}{|c|c|c|c|c|c|c|}
\hline \multicolumn{2}{|c|}{$\gamma$} & \multicolumn{2}{|c|}{ أحياناً } & \multicolumn{2}{|c|}{ دائماً } & أي نـوع مـن الصحافـة \\
\hline النسبة & التكر ارات & النسبة & التكرار ات & النسبة & التكرارات & 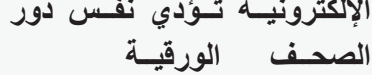 \\
\hline$\% \leqslant V$ & rᄉ & $\% 1$ & r^ & $\% r r$ & $r \varepsilon$ & الصحافة الإكترونية الحكومية \\
\hline$\% 10$ & Ir & $\% 01$ & $\leqslant 7$ & $\% \leqslant V$ & or & الصحافة الإكترونية الأهلية \\
\hline$\% \mu \wedge$ & r. & $\% 1 \wedge$ & 17 & $\%$ & $r \varepsilon$ & الصحافة الإكترونية الحزبية \\
\hline$\% 1 \ldots$ & $\Lambda$. & $\% 1 \ldots$ & 9. & $\% 1 \ldots$ & 11. & المجموع \\
\hline
\end{tabular}

تدل نتائج الجدول رقم (r ا) على الآتي:

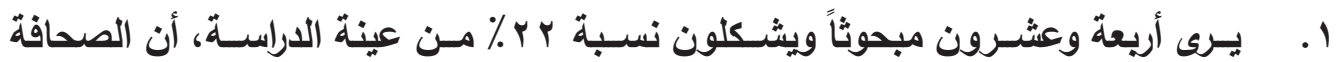

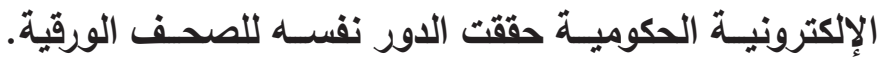

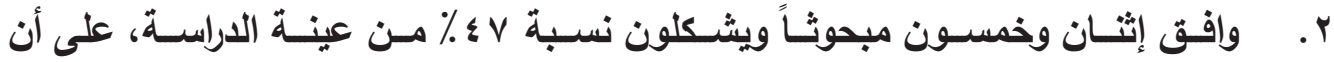

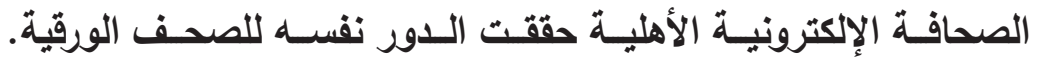

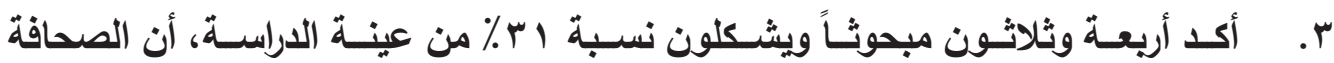

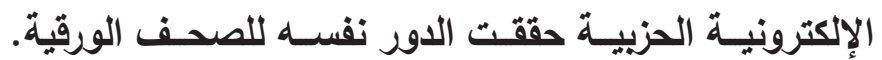

خمسة عشر: أسباب عدم تأدية الصحافة الإلكترونية لدور الصحف الورقية:

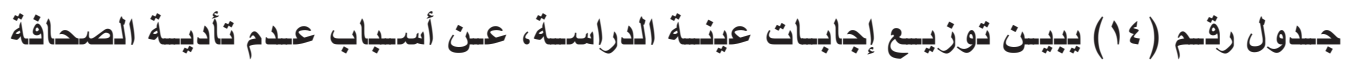
الإلكترونيـة لذفس دور الصدف الدف الورقيسة.

\begin{tabular}{|c|c|c|c|}
\hline الترتيب & النسبة المئوية & التكرارات & أسباب عدم تأدية الصحافة الإكترونية لدور الصحف الورقية \\
\hline r & $\% Y r$ & 74 & صعوبة استخدامها من جهة كافة افراد المجتمع \\
\hline$r$ & $\%$ & $0 \wedge$ & تحتاج إلى متطلبات مادية وفنية من أجهزة وتقتيات \\
\hline 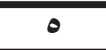 & $\% 11$ & $r \cdot$ & ضعف تأهيل الصحفيين العاملين في الصحافة الإكترونية \\
\hline$\varepsilon$ & $\% 17$ & $\leqslant 7$ & ابتعاد الصحفي الإكتروني عن الالتزام بأخلاقيات المهنة \\
\hline 1 & $\%$ & $\mathrm{~V} \varepsilon$ & سيطرة أساليب الدعاية السياسية والإثارة في مضمونها \\
\hline 7 & $\% \varepsilon$ & $1 \cdot$ & صعوبات أخرى. \\
\hline & $\%$ & $r \wedge$. & المجموع \\
\hline
\end{tabular}

مجلة الباحث الاعلامي| 


\section{تدل نتائج الجدول رقم (ء ا) على الآتي:}

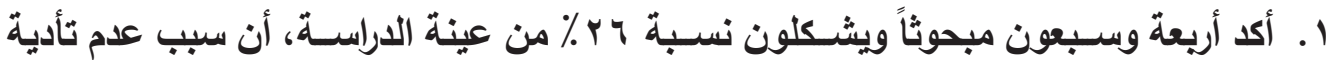
الصحافة الإكترونية لنفس دور الصحافة الورقية هو سـيطرة أسـاليب الدعاية السياسـية والإثارة في مضمونها.

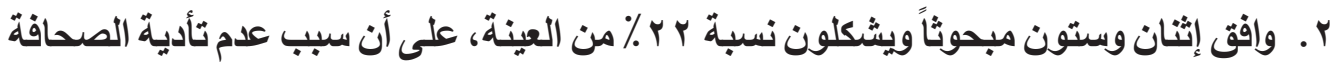

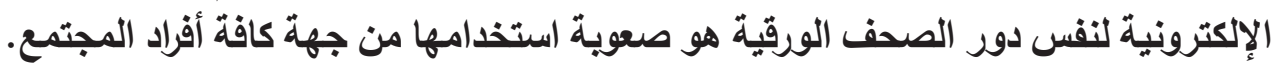

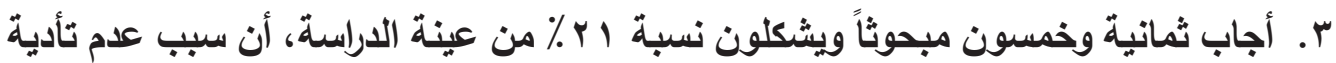

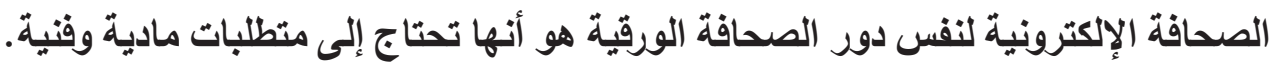

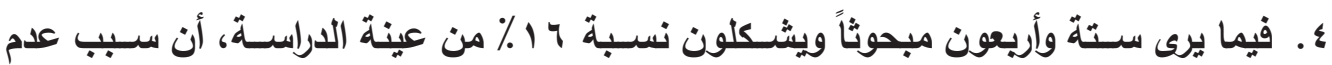

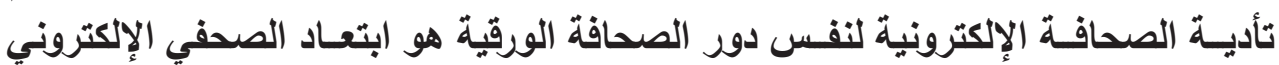
عن الالتـزام بأخلاقيات المهنة.

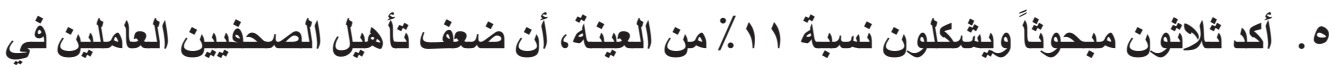

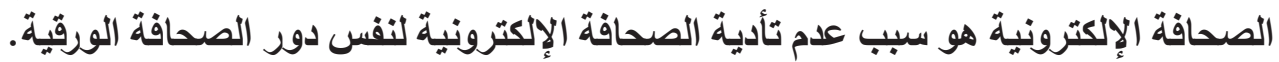

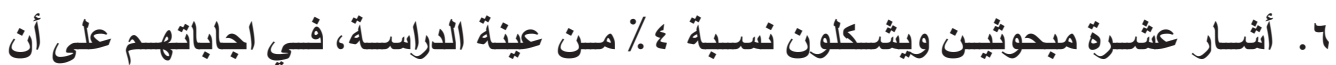

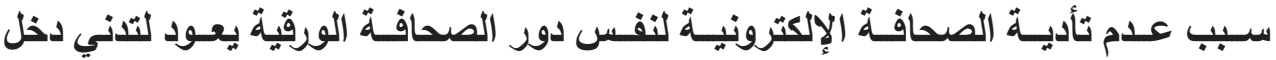

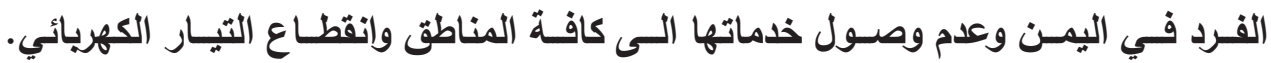

ستة عشر: مساحة حرية التعبير عن الرأي تبرز بشكل واسع: جـول رقـم (10) يوضـح آراء المبحوثيـن، عن مســاحة حريـة التعبير عن الـرأي التي تبرز

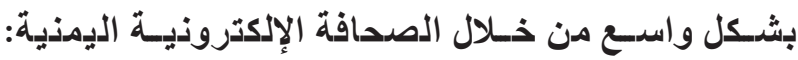

\begin{tabular}{|c|c|c|c|c|c|c|}
\hline \multicolumn{2}{|r|}{ لا } & \multicolumn{2}{|c|}{ أحياناً } & \multicolumn{2}{|c|}{ دائماً } & مســاحة حريــة التعبيـر عـن \\
\hline النسبة & التكرارات & النسبة & التكرارات & النسبة & التكرارات & 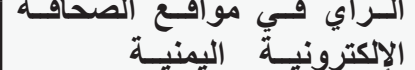 \\
\hline \% & r & $\% r q$ & rq & $\% \mathrm{VV}$ & rt & مواقع الصحافة الحكومية \\
\hline$\% 1 v$ & 1. & $\%\{$ & צ & $\%$ & $\vee \wedge$ & مواقع الصحافة الأهلية \\
\hline$\%$ r. & ir & $\% \mu 1$ & $r \wedge$ & $\% r r$ & $r$. & مواقع الصحافة الحزبية \\
\hline$\% 1 \ldots$ & 7. & $\% 1 \ldots$ & q. & $\% 1 \ldots$ & ir. & المجموع \\
\hline
\end{tabular}




\section{تدل نتائج الجدول رقم (0) على الآتي:}

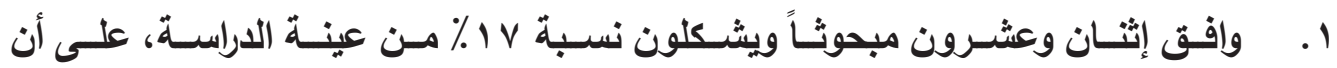

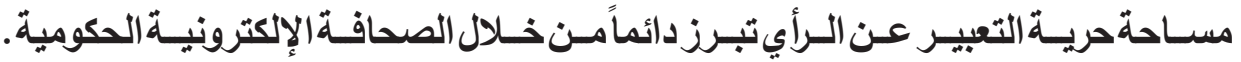

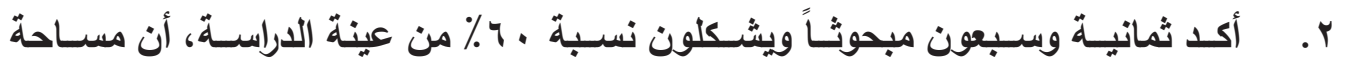

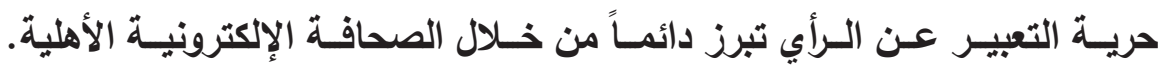

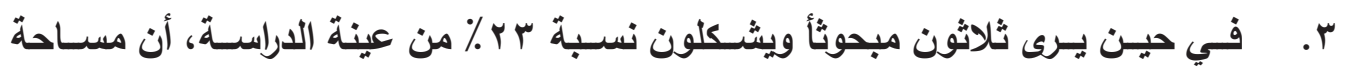

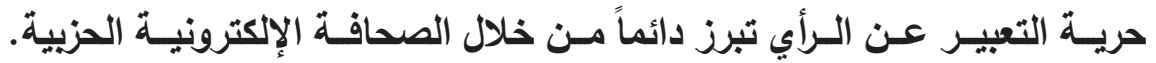

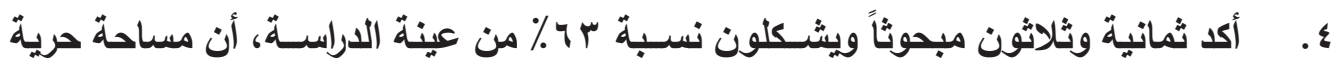

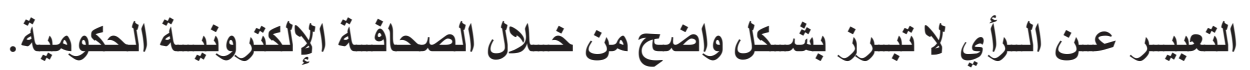

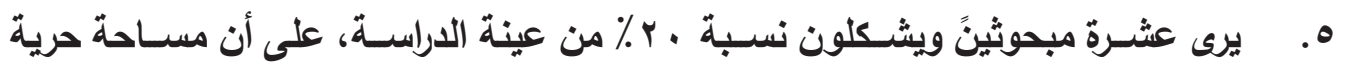

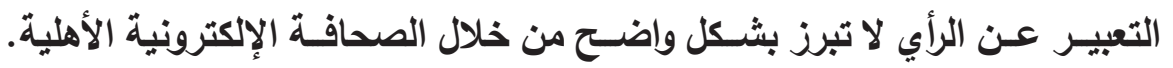

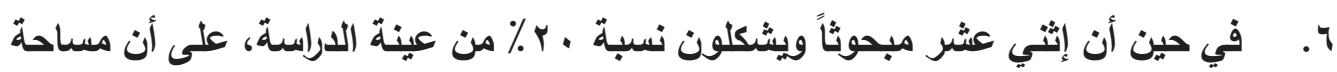

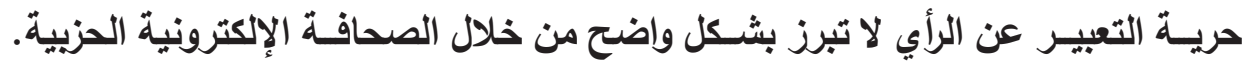

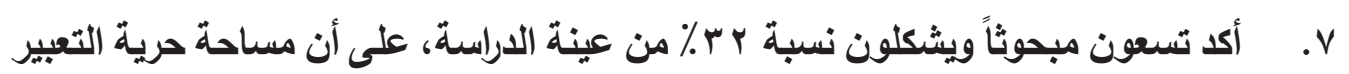

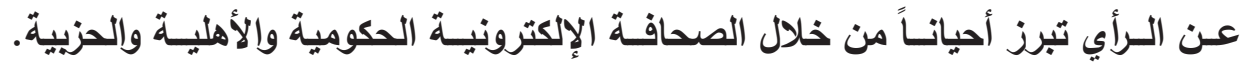

سبعة عشر: استغلال حرية التعبير عن الرأي من جهة الصحفي الإلكتروني:

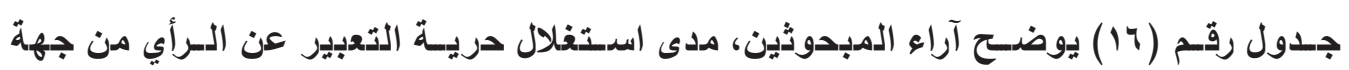

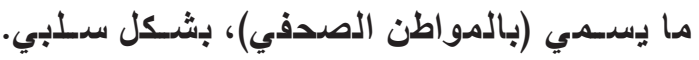

\begin{tabular}{|c|c|c|c|c|c|c|}
\hline \multicolumn{7}{|c|}{ مدى استغلال حرية التعبير عن الرأي من جهة ما يسمي (بالمواطن الصحفي) } \\
\hline \multicolumn{2}{|r|}{$\bar{y}$} & \multicolumn{2}{|c|}{ أحياناً } & \multicolumn{2}{|c|}{ نعم } & \multirow{2}{*}{ 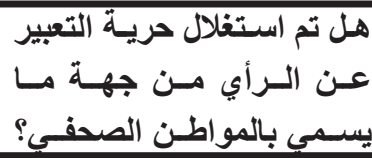 } \\
\hline النسبة & التكرارات & النسبة & التكرارات & النسبة & التكرارات & \\
\hline$\%$ & 10 & $\% r V$ & 75 & $\% \leqslant r$ & $1 \%$ & المجموع \\
\hline
\end{tabular}

تشير نتائج الجدول رقم († 1) إلى الآتي:

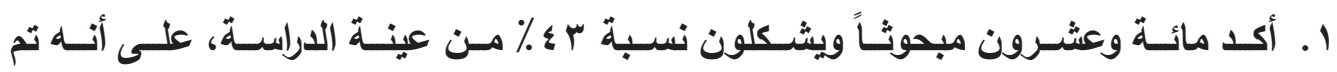

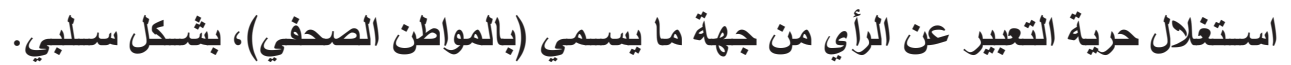




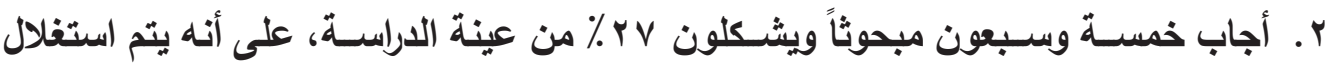

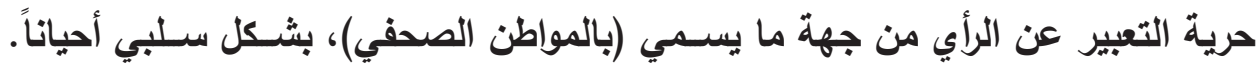

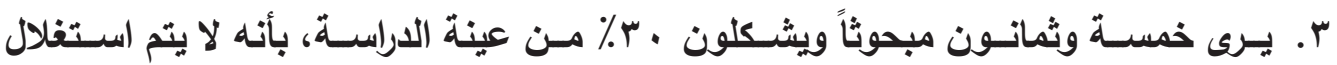

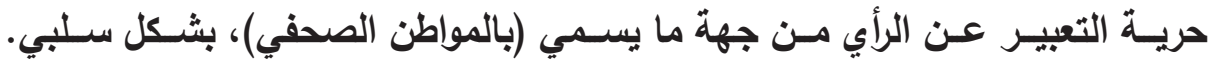
سبعة عشر: طبيعة القضايا الأكثر حضوراً في مواقع الصحافة الإلكترونية: جدول رقم (IV) يبين طبيعة القضايا الأكثر حضـوراً في مواقع الصدافة الإلكترونية.

\begin{tabular}{|c|c|c|c|}
\hline الترتيب & النسبة المئوية & التكرارات & القضايـا الأكثر حضوراً في مو اقع الصحافة الإكترونية \\
\hline$\varepsilon$ & $\% 11$ & ○. & قضايا تتصل بمصالح الأفراد وخصوصيتهم \\
\hline r & $\%$. & 07 & قضايا تتصل بنشر معلومات سرية \\
\hline r & \%r & $7 \varepsilon$ & قضايا تتصل بالدعاية و الترويج للشائعات \\
\hline • & $\% \vee$ & r. & قضايا تتصل بالإساءة للقيم و العادات و التقاليد \\
\hline 1 & $\%$ \% & $\wedge$. & قضايا الإساءة إلى رموز النظام السياسي في البلا \\
\hline 4 & $\% r$ & 1. & قضايا أخرى \\
\hline \multicolumn{2}{|r|}{$\% 1 \ldots$} & rA. & المجموع \\
\hline
\end{tabular}

تشير نتائج الجدول رقم (vil) إلى الآتي:

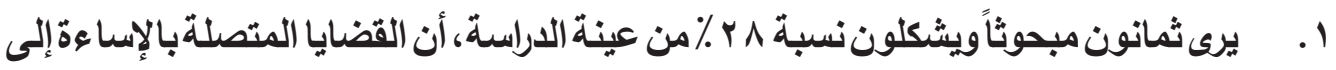

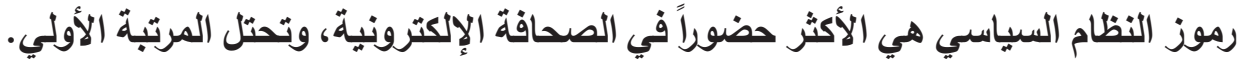

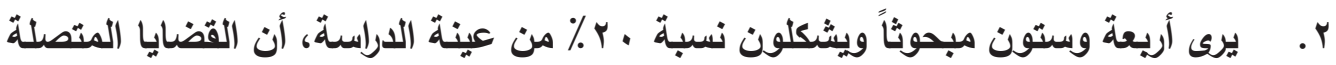

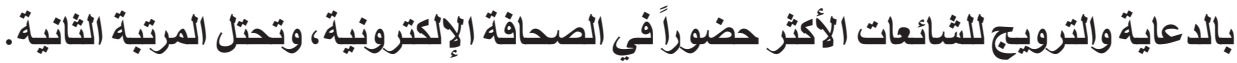

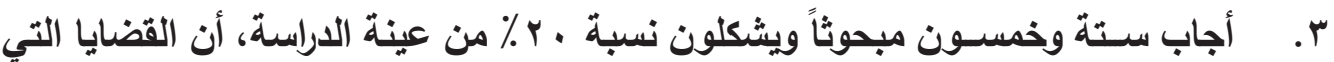

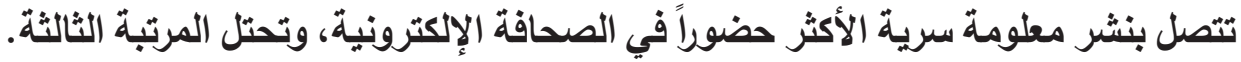

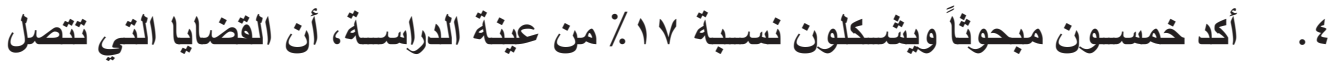

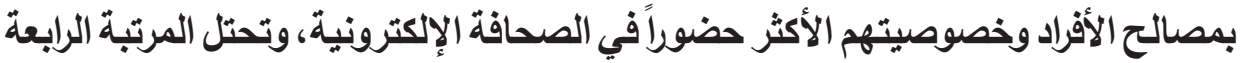
ه. يرى عشرون مبحوثاً ويشكلون نسبة ^٪ من عينة الاراسة، أن القضايا التي تتصل بالإساءة

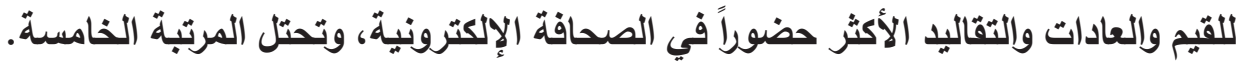




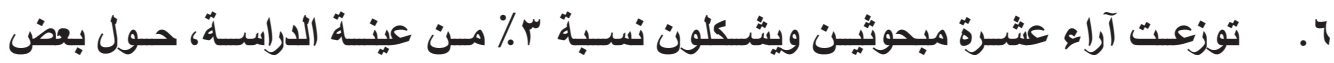

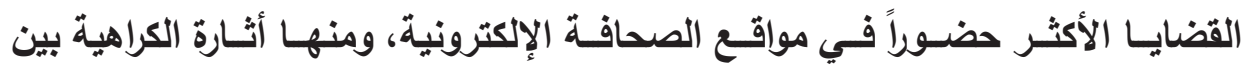
أبنـاء الوطـن، وعدم تحسـين اللحمـة الوطنية.

ثمانية عشر:الصحافة الإلكترونية والرقيب الحكومي على الصحف الورقية: جـدول رقـم (1) يبيسن توزيـع إجابـات عينـة الدراسـة، عـن الصدافـة الإككترونيـة ودور الرقيـب الحكومسي علـى الصدف الورقيـة.

\begin{tabular}{|c|c|c|c|c|c|c|}
\hline \multicolumn{7}{|c|}{ الصحافة الإكترونية ودور الرقيب الحكومي على الصحف الورقية } \\
\hline \multicolumn{2}{|c|}{ لا } & \multicolumn{2}{|c|}{ أحياناً } & \multicolumn{2}{|c|}{ نعم } & \multirow{2}{*}{ 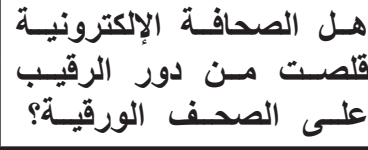 } \\
\hline 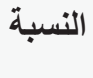 & 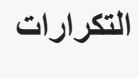 & 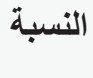 & 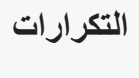 & 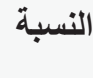 & 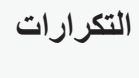 & \\
\hline$\%$ & $9 \leq$ & $\% r v$ & V & $\% q q$ & 11. & المجموع \\
\hline
\end{tabular}

\section{تدل نتائج الجدول رقم (1/) إلى الآتي:}

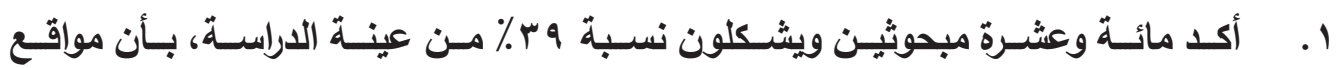

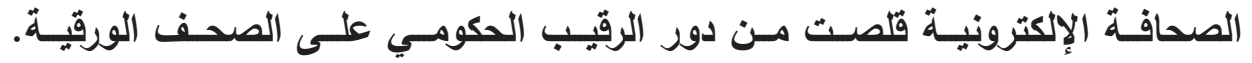

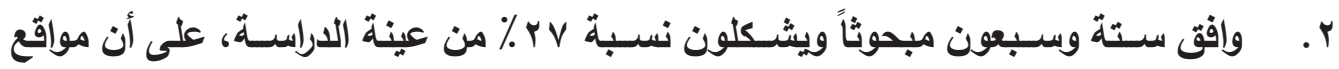

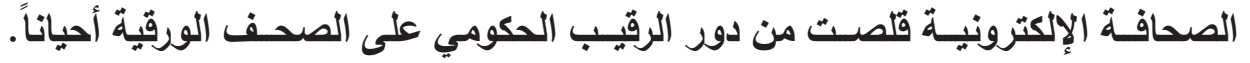

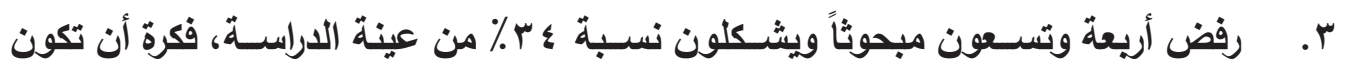

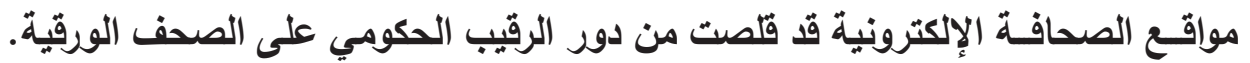

\section{نتائج وتوصيات الدراسة}

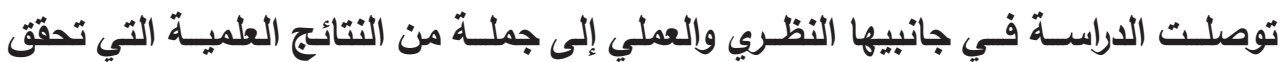

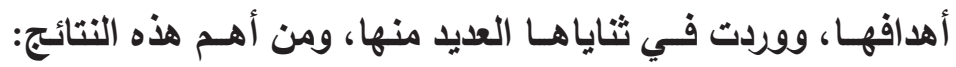

\section{أولاً: نتائج الدراسة في الجانب النظري:}

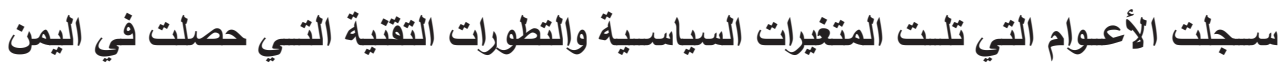

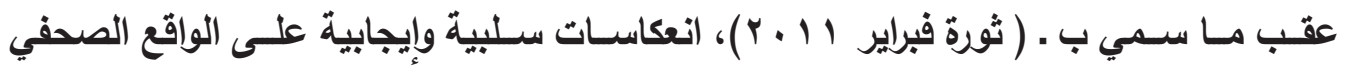

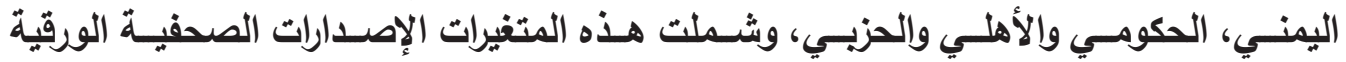

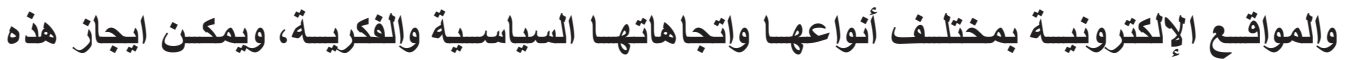
المتغيـرات والانعكاسـات الإيجابية والسـلبية،من خلال النقاط النـاط الآتية:

مجلة الباحث الاعلامي| 


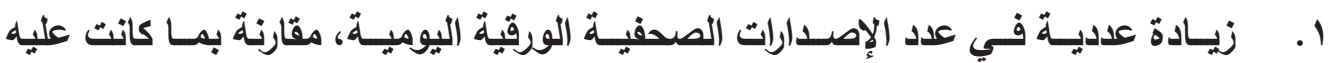

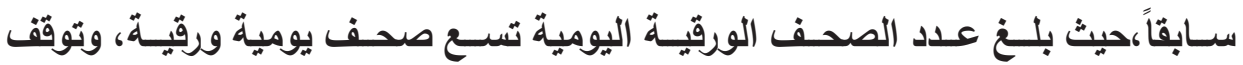
صحيفـة السياسـية الورقية اليوميـة الحكومية عـن الصدور. r. تحـول بعض الصحف الأسـبوعية الورقية الأهلية من الإصدار الأسـبوعي إلى الصدور بشـكل يومي منتظم، مثل صحف الثـارع والمصدر والأمناء.

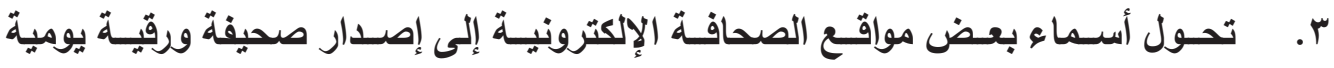

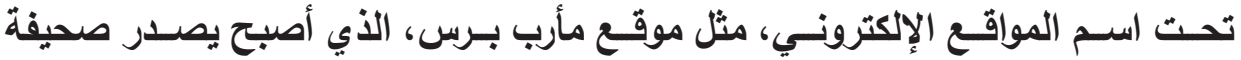

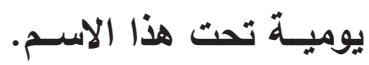
ع. زيـادة مسـتمرة في عـد مواقع الصحافـة الإكترونية، حيث بلغ عـدد المواقع الإخبارية

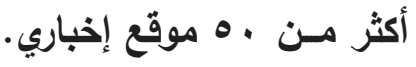

\section{ثانياً: أهم نتائج الدراسة الميدانية:}

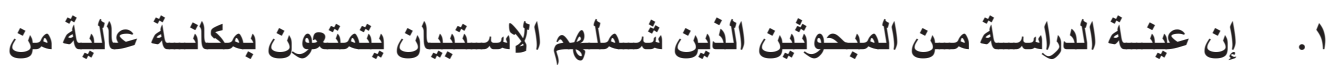

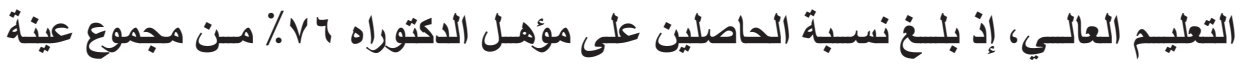

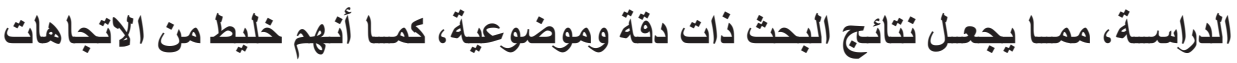
السياسـية والفكرية المختلفة.

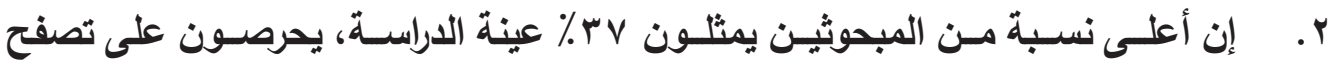

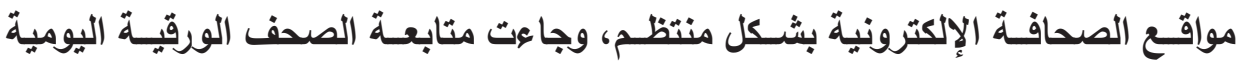

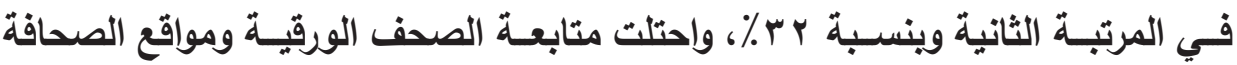

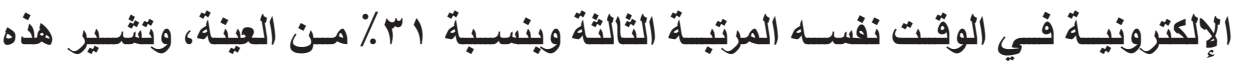

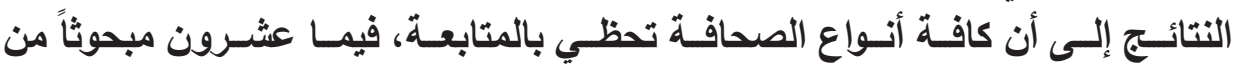

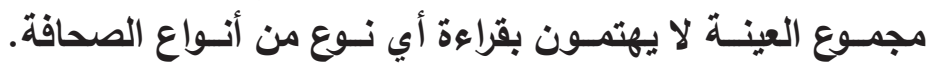

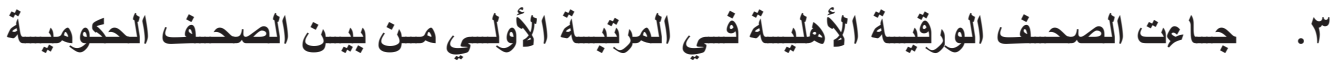

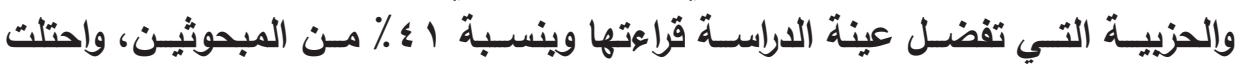

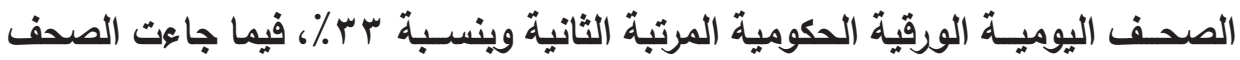

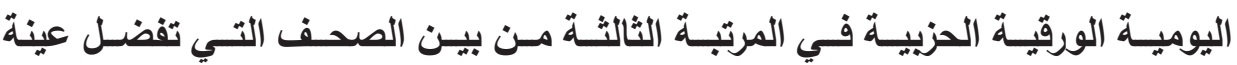

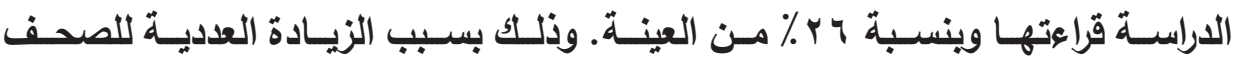

\begin{tabular}{|c|c|}
\hline & مجلة الباحث الاعلامي| \\
\hline$M \Lambda \Lambda$ & العدد ( rץ ) \\
\hline
\end{tabular}




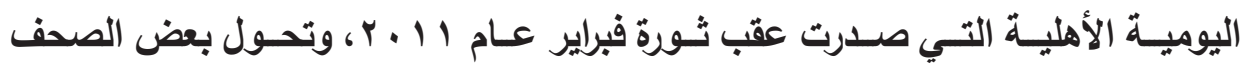

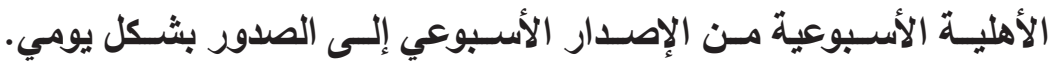

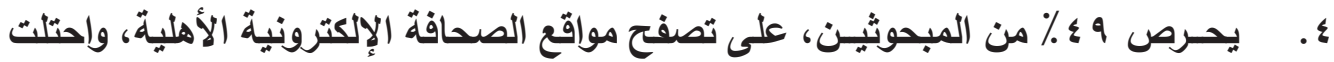

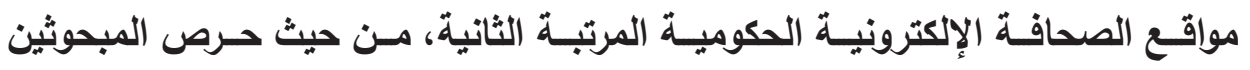

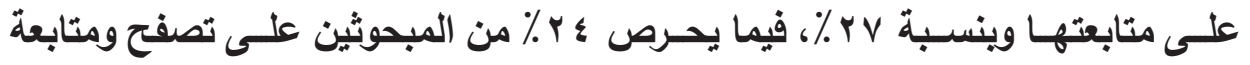

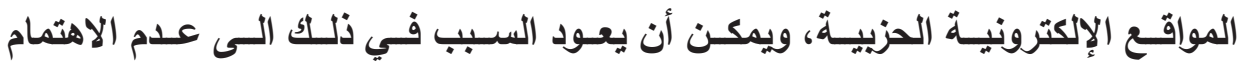

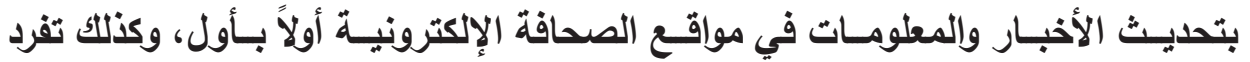

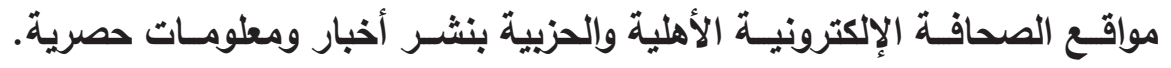

هـ جـاعت الصحـف الورقيـة الأهلية في مقدمة الصحف اليومية التي تفضل عينة الدراســة

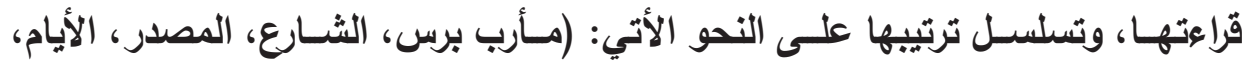

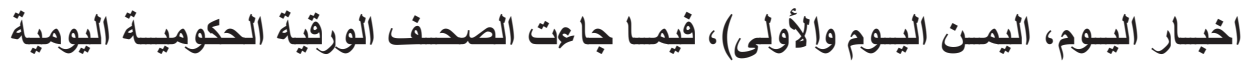

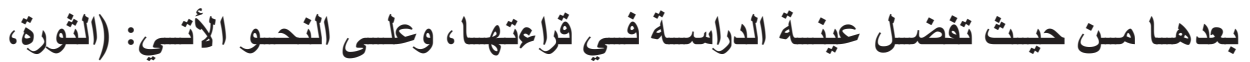

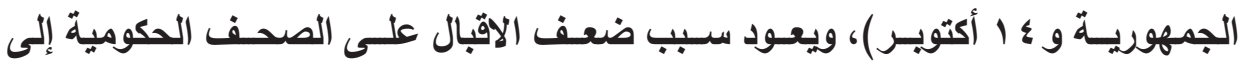

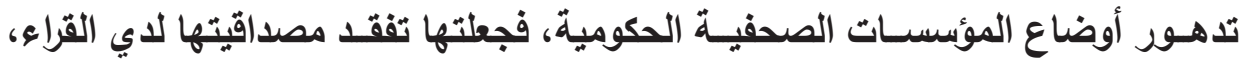
وتوقف إحـى الصحف اليومية الحكومية عـن الصدور، وهي السياسـية.

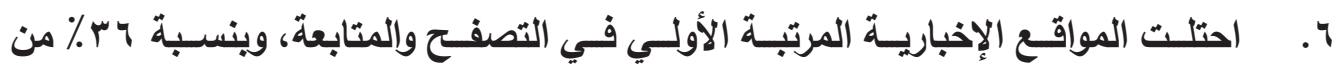

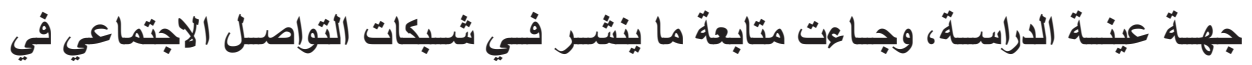

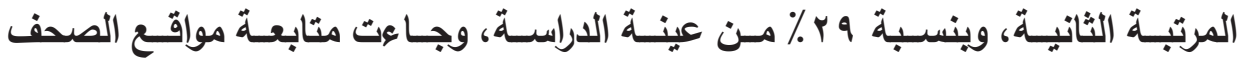

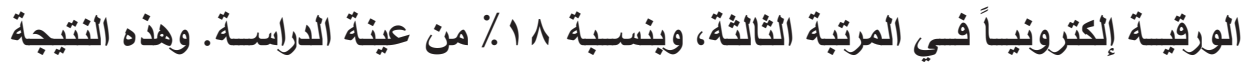

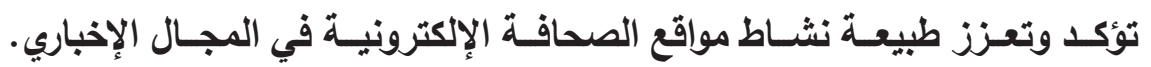

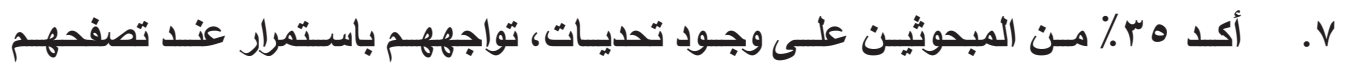

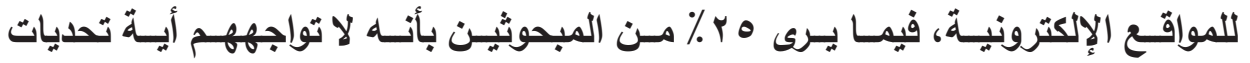

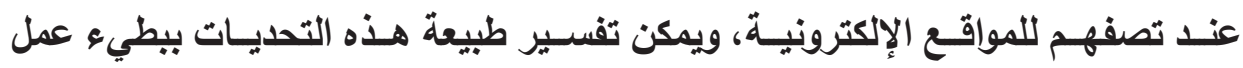

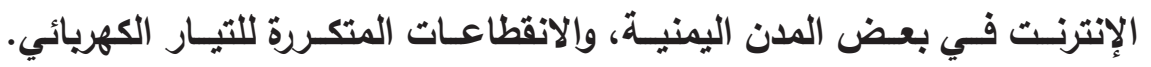

^. جاءت الأخبار المحلية في المرتبة الأولي من بين المواضيع التي تحرص عينة الدراسـة

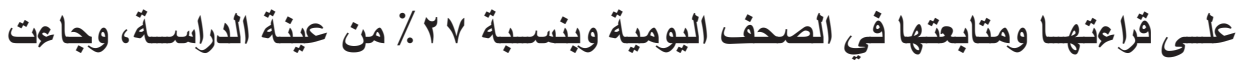




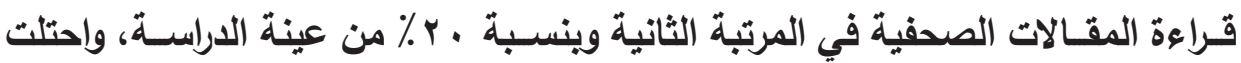

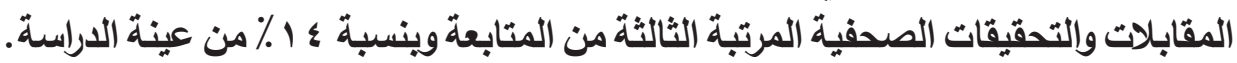

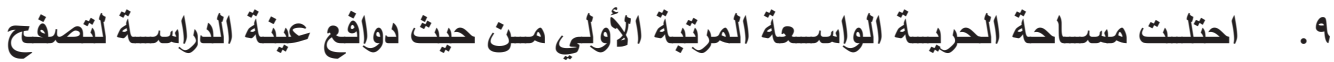

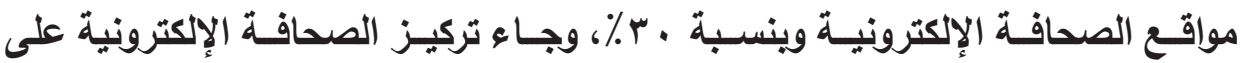

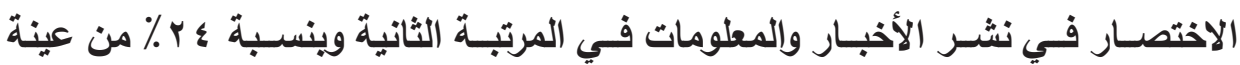

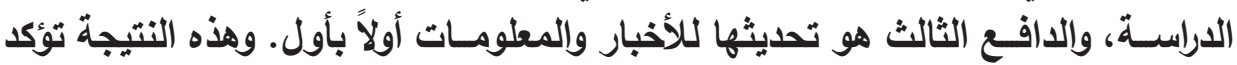

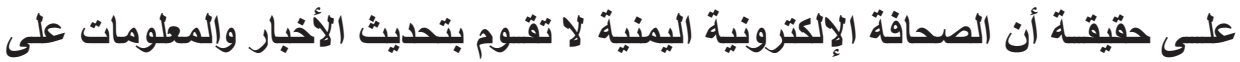
مدى أريعة وعشـرين ساعة.

• 1 . وافق ب ٪ من المبحوثين على أن الصحافة الإكترونية تثكل تهديداً حقيقاً لاستمرارية

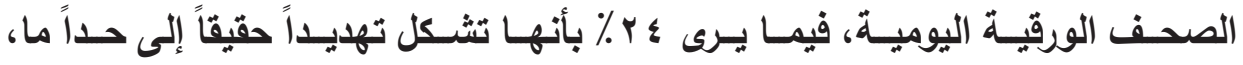

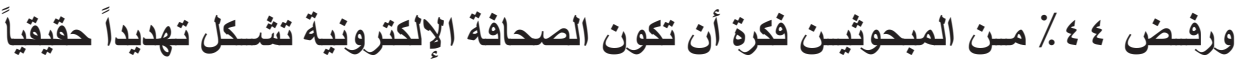

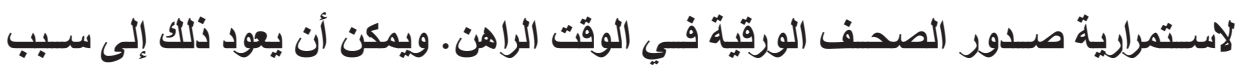
التحديـات التـي تواجه متصفحي مواقِّع الصحافة الإكترونية.

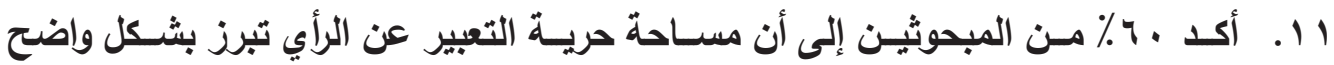

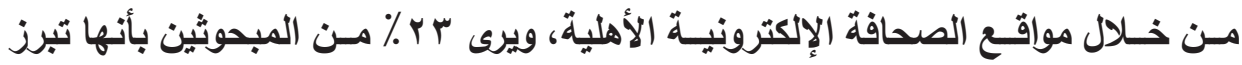

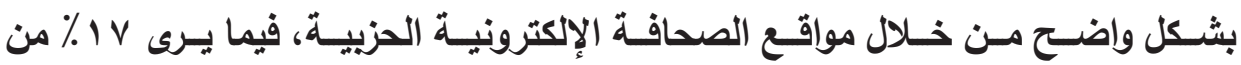

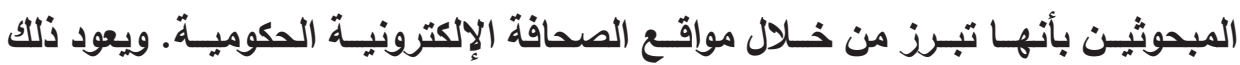

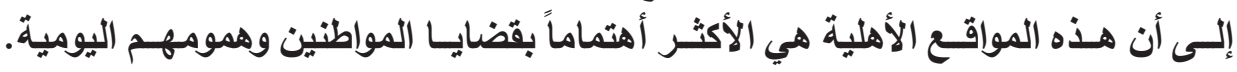

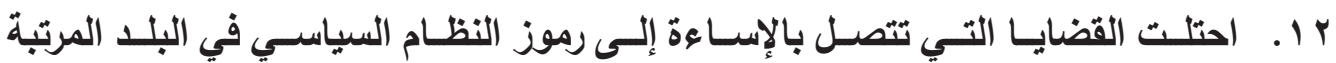

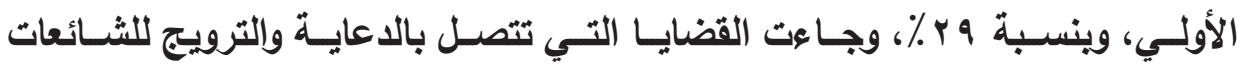

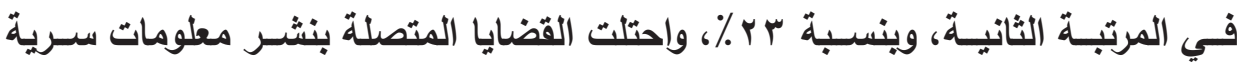

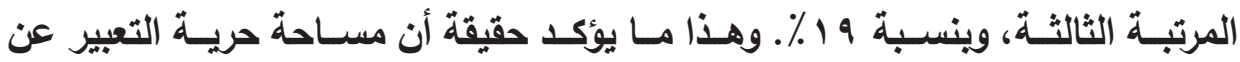
الـرأي تبـرز بشـكل واضـح في مواقـع الصحافـة الإكترونيـة الأهلية.

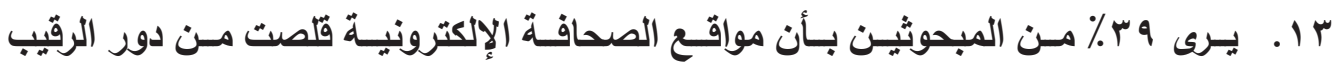

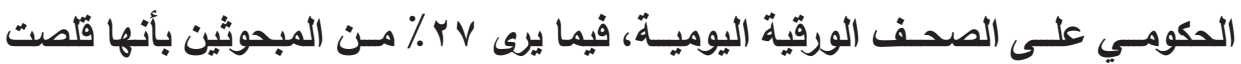




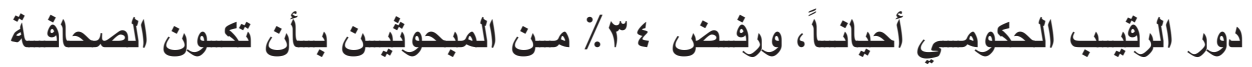

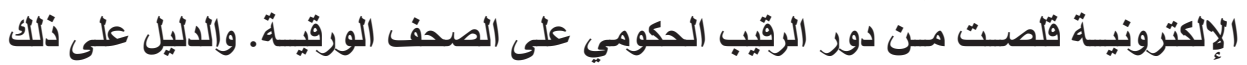

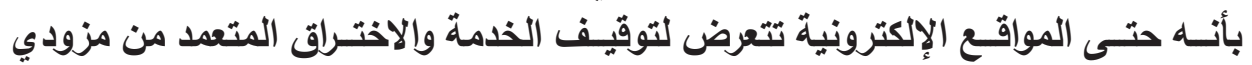
الخدمسة في الجهات المئه الحكومية.

\section{ثالثاً: توصيات الدراسة}

1. ينبخي أن تتجه الصحافة الورقية اليومية إلى التميز والأبداع في نشر الأخبار الحصرية،

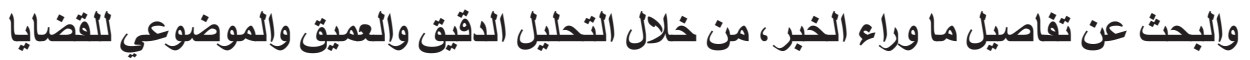
المطروحة على السـاحة، حتى تسـتطيع أن تستمر وتنافس مواقع الصحافة الإلكترونية.

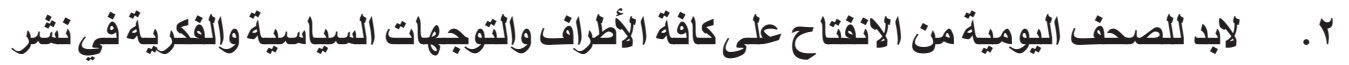

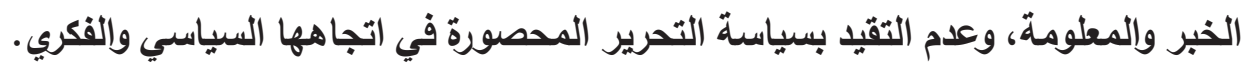

r. التوســع فـي متابعـة القضايا التي تمس حيـاة المواطن اليومية وطرحها بأســلوب مهني

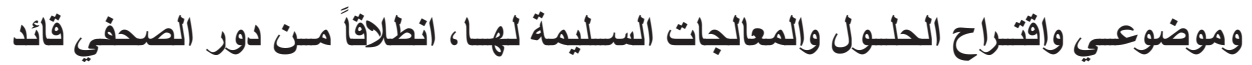
في المجتمع.

؛. أسـتخدام الأسـاليب القنية الحديثة في عملية التحرير الصحفي، ويعّد أسـلوب الصحافة الاستقصائية أحد الضمانات التي يمكن أن تعزز ثقة جمهور القراء بالصحف الوئية الورقية اليومية.

ه. الأبتعاد عن تناول التحيزات السياسية والفكرية التي تخدم مصالح وأهداف ضيقة، وعدم أثثارة القضايا التي تعزز مفهوم الكراهية والمناطقية والطائفية، في الصحف الورية التية اليومية الئية.

\begin{tabular}{l|c} 
& مجلة الباحث الاعلامي| العدد (r ) \\
\hline 191 & (T)
\end{tabular}




\section{المصادر والمراجع:}

(Endnotes)

ا. ـ دـ محمـــ منيـر حجـاب، أسـاسـيات البحوث الإعلاميـة والاجتماعية، القاهـرة: دار الفجر للنشـر والتوزيع،

$$
\text { Vru }
$$

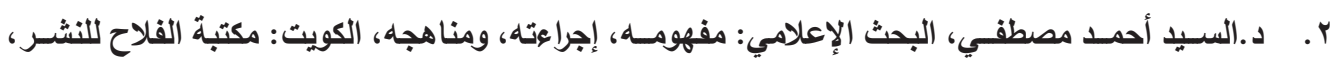

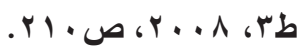

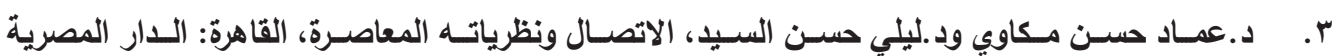

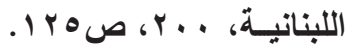

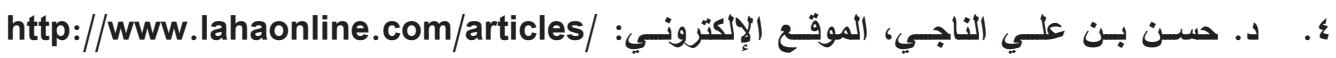

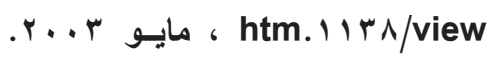

ه. د. رضا عبد الواحد أمين، الصحافة الإكترونية، القاهرة: دار القجر للنشر والتوزيع، V . . r، صه ص. 4. د. عبد الأمير الفيصل، الصحافة الإكترونية في الوطن العربي، عمان : دار الثروق للنشر والتوزيع، ص V .

V. صبـاح عبده هادي الخيشــي، دور التحقيق الصحفي في معالجة قضايـا المجتمع في الصحافة اليمنية:

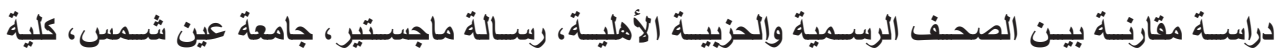

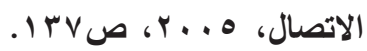

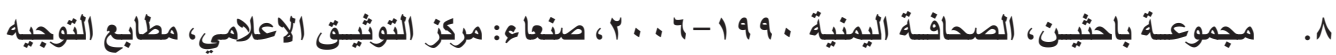

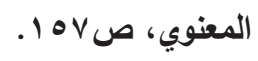

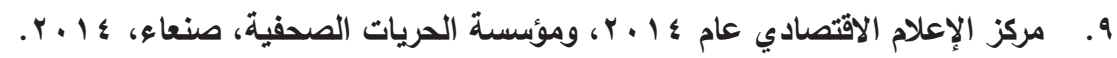

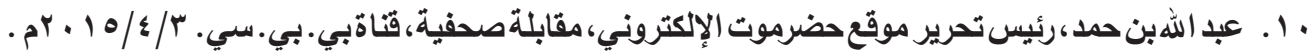

*-يلاحظ في بعض الجداول زيادة عدد التكرارات علي عدد المبحوثين، وذلك بسبب طبيعة الأسئلة

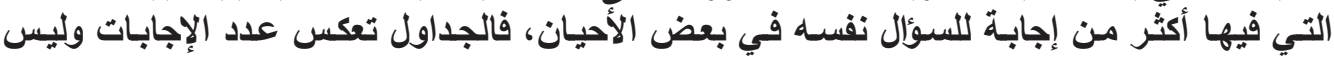
عدد المبحوثين. 